medRxiv preprint doi: https://doi.org/10.1101/2021.08.10.21261777; this version posted August 13, 2021. The copyright holder for this preprint (which was not certified by peer review) is the author/funder, who has granted medRxiv a license to display the preprint in It is made available under a CC-BY-ND 4.0 International license .

\title{
Testing Denmark: A Danish nationwide surveillance study of COVID-19
}

Kamille Fogh ${ }^{1,2}$ MD., Jarl E Strange ${ }^{1}$ MD., Bibi FSS Scharff ${ }^{3}$ PhD., Alexandra RR Eriksen ${ }^{1,2}$ B. Med., Rasmus B Hasselbalch ${ }^{1,2}$ MD., Henning Bundgaard ${ }^{4}$ DMSc., Susanne D Nielsen ${ }^{5}$ DMSc., Charlotte S Jørgensen ${ }^{6}$ PhD., Christian Erikstrup PhD, Jakob Norsk ${ }^{1,2}$ MD., Pernille Brok Nielsen ${ }^{1,2}$ MD., Jonas H Kristensen ${ }^{1,2}$ MD., Lars $\emptyset$ stergaard ${ }^{7}$ DMSc., Svend Ellermann-Eriksen ${ }^{8}$ DMSc., Berit Andersen ${ }^{9}$ MD., Henrik Nielsen ${ }^{10}$ DMSc., Isik S Johansen ${ }^{11}$ DMSc., Lothar Wiese ${ }^{12}$ PhD., Lone Simonsen ${ }^{13}$ PhD, Thea K.Fischer ${ }^{14}$ DMSc., Fredrik Folke ${ }^{1,15}$ PhD., Freddy Lippert ${ }^{15}$ MD., Sisse R Ostrowski ${ }^{3}$ DMSc, Thomas Benfield ${ }^{16}$ DMSc., Kåre Mølbak ${ }^{17}$ DMSc., Steen Ethelberg ${ }^{18}$ PhD., Anders Koch ${ }^{5,17}$ PhD, Ute Wolff Sönksen ${ }^{6}$ MD., Anne-Marie Vangsted ${ }^{6}$ MPharm., Tyra Grove Krause ${ }^{6}$ MD., Anders Fomsgaard ${ }^{6}$ DMSc., Henrik Ullum ${ }^{6}$ PhD., Robert Skov ${ }^{6}$ MD., Kasper Iversen ${ }^{1,2}$ DMSc.

1. Department of Cardiology, Copenhagen University Hospital, Herlev and Gentofte, Denmark*

2. Department of Emergency Medicine, Copenhagen University Hospital, Herlev and Gentofte, Denmark*

3. Department of Clinical Immunology, Copenhagen University Hospital, Rigshospitalet, Denmark*

4. Department of Cardiology, Copenhagen University Hospital, Rigshospitalet, Denmark*

5. Department of Infectious Diseases, Copenhagen University Hospital, Rigshospitalet, Denmark*

6. Statens Serum Institut, Copenhagen Denmark

7. Department of Infectious Diseases, Aarhus University Hospital, Aarhus, Denmark**

8. Department of Clinical Microbiology, Aarhus University Hospital, Aarhus, Denmark**

9. University Research Clinic for Cancer Screening, Randers Regional Hospital, Randers, Denmark**

10. Department of Infectious Diseases, Aalborg University Hospital, Aalborg, Denmark***

11. Department of Infectious Diseases, Odense University Hospital, Odense, Denmark****

12. Department of Infectious Diseases, Zealand University Hospital, Roskilde, Denmark

13. Department of Science and Environment, Roskilde University, Denmark

14. Department of Clinical Research, North Zealand Hospital, Hillerød, Denmark*****

15. Copenhagen Emergency Medical Services, Copenhagen, Denmark*

16. Department of Infectious Diseases, Copenhagen University Hospital, Amager and Hvidovre, Hvidovre, Denmark*

17. Statens Serum Institut, Copenhagen, Denmark*****

18. Statens Serum Institut, Copenhagen, Denmark ${ }^{* * * * * *}$

* and Department of Clinical Medicine, University of Copenhagen, Copenhagen, Denmark

** and Department of Clinical Medicine, Aarhus University, Aarhus, Denmark

*** and Department of Clinical Medicine, Aalborg University, Odense, Denmark

**** and Department of Clinical Research, University of Southern Denmark, Odense, Denmark

***** and Department of Veterinary and Animal Sciences, University of Copenhagen, Frederiksberg C,

Denmark

****** and Department of Public health, University of Copenhagen, Copenhagen, Denmark

Corresponding author:

Kamille Fogh, MD

E kamille.fogh.01@regionh.dk 
medRxiv preprint doi: https://doi.org/10.1101/2021.08.10.21261777; this version posted August 13, 2021. The copyright holder for this preprint (which was not certified by peer review) is the author/funder, who has granted medRxiv a license to display the preprint in It is made available under a CC-BY-ND 4.0 International license .

\section{Abstract}

\section{Background}

National data on the spread of SARS-CoV-2 infection and knowledge on associated risk factors are important for understanding the course of the pandemic. "Testing Denmark" is a national large-scale epidemiological surveillance study of SARS-CoV-2 in the Danish population.

\section{Methods}

Between September and October 2020, approximately 1.3 million of 5.8 million Danish citizens (age > 15 years) were randomly invited to fill in an electronic questionnaire covering COVID-19 exposures and symptoms. The prevalence of SARS-CoV-2 antibodies was determined by Point-of Care rapid Test (POCT) distributed to participants home addresses.

\section{Findings}

In total 318,552 participants ( $24.5 \%$ invitees) completed the questionnaire and provided the result of the POCT. Of these, 2,519 (0.79\%) were seropositive (median age 55 years) and women were more often seropositive than men, interquartile range (IQR) 42-64, 40.2\% males. Of participants with a prior positive Polymerase Chain Reaction (PCR) test ( $n=1,828), 29.1 \%$ were seropositive in the POCT. Seropositivity increased with age irrespective of sex. Elderly participants (>61 years) reported less symptoms and had less frequently been tested for SARS-CoV-2 compared to younger participants. Seropositivity was associated with physical contact with SARS-CoV-2 infected individuals (Risk ratio (RR) 7.43, 95\% Cl: 6.57-8.41) and in particular household members (RR 17.70, 95\% Cl: 15.60-20.10). Home care workers had a higher risk of seropositivity (RR 2.09 (95\% Cl: 1.58-2.78) as compared to office workers. Geographic population density was not associated to seropositivity. A high degree of compliance with national preventive recommendations was reported (e.g., > $80 \%$ use of face masks), but no difference was found between seropositive and seronegative participants.

\section{Interpretation}

This study provides insight into the immunity of the Danish population seven to eight months after the first COVID-19 case in Denmark. The seroprevalence was lower than expected probably due to a low sensitivity of the POCT used or due to challenges relating to the reading of test results. Occupation or exposure in local communities were major routes of infection. As elderly participants were more often seropositive despite fewer symptoms and less PCR tests performed, more emphasis should be placed on testing this age group. 
medRxiv preprint doi: https://doi.org/10.1101/2021.08.10.21261777; this version posted August 13, 2021. The copyright holder for this preprint (which was not certified by peer review) is the author/funder, who has granted medRxiv a license to display the preprint in It is made available under a CC-BY-ND 4.0 International license .

\section{Introduction}

National seroprevalence data on antibodies to SARS-CoV-2 can guide national health policies in understanding transmission routes and thereby improve the management of potential new outbreaks during the COVID-19 pandemic (1-4). However, a large sample size is required to describe the spread of infection, risk factors, and severity of the infection across geography and demography (5).

Denmark has 5.8 million inhabitants (6) and as of July 5, 2021, there have been more than 295,654 (5\%) confirmed cases of SARS-CoV-2 infection and more than 2,537 COVID-19 related deaths in Denmark (7). The first confirmed case of SARS-CoV-2 infection in Denmark was reported on February 27, 2020 (8). In Denmark, the epidemic has been characterized by two infection waves; spring 2020 and autumn-winter 2020/2021, similar to several other European countries (9). Two lockdowns were imposed by the government, the first between March 11th to April 15th, 2020 and the second December 17th, 2020 to February 8th, 2021 (10). Testing for SARS-CoV-2 in Denmark using Polymerase Chain Reaction (PCR) was established in March 2020 and has been upscaled during the pandemic. From March 12 to April 21, 2020 individuals with moderate to severe symptoms of respiratory tract infection were offered testing. From April 21, 2020 testing was available for individuals with mild symptoms and asymptomatic contacts, and since May 18, 2020, nationwide high-intensity, free of charge testing for SARS-CoV-2 infection has been performed using PCR (11). Vaccination against COVID-19 began on December $27^{\text {th }}, 2020$ with residents and employees at nursing homes and frontline staff at hospitals (12).

The rates of COVID-19-related morbidity and mortality have been low in Denmark compared to other European countries (13). Nevertheless, considering the unknown proportion of asymptomatic or mildly symptomatic SARS-CoV-2 infected persons who have not been PCR-tested (viral throat- and nasopharyngeal swab), the population exposure to infection might be higher than reported according to PCR test findings (1). The seroprevalence has been reported for different groups in Denmark; blood donors (14), medical students (15), health care workers (16), a smaller national random selection of the population (10), homeless persons and sex workers (17) and persons from social housing areas (18), but hitherto no national investigation of this scale has been performed in Denmark.

"Testing Denmark" was a nationwide surveillance study of SARS-CoV-2 infection in the Danish population, launched in September 2020. The study was divided in 2 phases; phase 1 (the general population) and phase 2 (subgroups). In this article, we describe the process and results of phase 1 . Results from phase 2 have been described elsewhere $(17,18)$. 
medRxiv preprint doi: https://doi.org/10.1101/2021.08.10.21261777; this version posted August 13, 2021. The copyright holder for this preprint (which was not certified by peer review) is the author/funder, who has granted medRxiv a license to display the preprint in It is made available under a CC-BY-ND 4.0 International license.

61 The aim of this study was to explore possible risk factors for seropositivity by questionnaire data, and to determine the distribution of SARS-CoV-2 antibodies among Danish citizens over the age of 15 years, by the use of Point-of care rapid test (POCT) for antibodies against SARS-CoV-2.

\section{Methods}

\section{Study design and participation}

1.3 million Danish citizens over the age of 15 years ( $22 \%$ of the population) were randomly drawn from the Civil Registration System (19) and invited to participate via the governmental, personal, passwordprotected digital mailbox system (e-Boks) from September 25, 2020. Written information about the project was available in 3 different languages; Danish, English and Arabic.

Participants were invited to complete a web-based questionnaire by a link (Enalyzer, Copenhagen, Denmark) in the invitation letter. The questionnaire included demographics, history of symptoms compatible with COVID-19, co-morbidities and substance use (see Appendix). In the questionnaire participants could further indicate if they wanted a POCT sent to their home address.

During October 2020 the POCT testing for SARS-CoV-2 IgG and IgM antibodies was performed by participants. Answers to the questionnaire and the result of the POCT results were registered by the participant in a secondary separate questionnaire sent to their e-Boks and returned to Enalyzer.

Detailed information about the test-procedure was provided with the invitation and could also be found at the project website (www.vitesterdanmark.dk), including instructional video on how to perform the POCT in practice, as well as videos with experts explaining different aspects of the study. Social media (Facebook and Instagram) were used for visualization. A call-center was set up for the participants to call in case of questions about the project, the questionnaire or how to perform the POCT.

Information about previous positive PCR test results amongst study participants was obtained from MiBa (The Danish Microbiological Database) that has complete coverage of all microbiological samples from general practice, hospitals and test facilities, analyzed by public laboratories (20).

\section{Detection of SARS-CoV-2 antibodies}

The Livzon POCT (Livzon Diagnostics, Zhuhai, Guangdong, China) was used. The POCT is a lateral flow chromatographic immunoassay rapid test for qualitative detection and differentiation of anti-SARS-CoV-2 IgG and IgM antibodies in whole blood, which yields results in 15 minutes. The manufacturer reported a 
medRxiv preprint doi: https://doi.org/10.1101/2021.08.10.21261777; this version posted August 13, 2021. The copyright holder for this preprint (which was not certified by peer review) is the author/funder, who has granted medRxiv a license to display the preprint in It is made available under a CC-BY-ND 4.0 International license .

combined test sensitivity (either IgG or IgM positive) of $90.6 \%$ (95\% Cl: $86.6 \%$ - 93.4\%) and a combined specificity (neither IgG nor IgM is positive) of $99.2 \%$ (95\% Cl: $97.6 \%$ - 99.7\%) (21). An in-house validation (cases $=150$ individuals, controls $=600$ individuals) showed sensitivity of $93.3 \%$ and $92.7 \%$ and specificity of 98.2\% and $97.5 \%$ for each of the two batches respectively (see appendix Table 4). The case panel samples were obtained from convalescent individuals within 2 months of disease onset. Sensitivity and specificity by self-use has not previously been studied.

The POCT was sent out with a small container of isotonic saline, capillary tubes, and fingerprickers.

Participants were instructed by the use of the capillary tubes to add blood by fingerprick and isotonic saline to each of the two test cassettes (IgG and IgM). The test results were read by participants individually; positive results counted when both control line and test line appeared, the test was inconclusive when no control line appeared or if the reading chamber was discolored by blood. Inconclusive test results were treated as negative, as the test could not be repeated, participants only receiving one POCT for both IgG and IgM. Participants were categorized as seropositive if they had developed either IgG or IgM antibodies, or both against SARS-CoV-2.

\section{Outcome measures}

The primary outcome of interest was to explore the association between SARS-CoV- 2 infection, defined as a positive SARS-CoV-2 antibody self-test result (IgG and/or IgM), and putative risk factors for seropositivity.

The proportion of the study population with a positive antibody test for SARS-CoV-2 (as a proxy for previous infection) was a secondary outcome of interest.

\section{Approvals, ethics and registrations}

This study was performed as a national surveillance study under the authority task of the national infectious disease control institute Statens Serum Institut (SSI), Copenhagen, Denmark. According to Danish law national surveillance activities from SSI do not require any individual approval from an ethics committee. The study was performed in agreement with the Helsinki Il declaration and registered with the Danish Data Protection Authorities (P-2020-901). Participation was voluntary and all data were selfreported. All personal data obtained in Enalyzer was kept in accordance with the general data protection regulation and data protection law stated by the Danish Data Protection Agency. Invitees received information about their legal rights and the use of their data in the invitation letter. 
medRxiv preprint doi: https://doi.org/10.1101/2021.08.10.21261777; this version posted August 13, 2021. The copyright holder for this preprint (which was not certified by peer review) is the author/funder, who has granted medRxiv a license to display the preprint in It is made available under a CC-BY-ND 4.0 International license .

\section{Statistical analyses}

Participants were considered seropositive if they tested positive for $\operatorname{lgG}$, IgM, or both antibodies. Baseline characteristics of seropositive compared to seronegative persons are presented as numbers and percentages for categorical values and continuous values are presented as medians and interquartile ranges. The Wilcoxon rank test and chi-square test were used for comparisons of groups for continuous and categorial values, respectively. Unadjusted risk ratios (RR) with $95 \%$ confidence intervals (CI) were calculated for risk factors of seropositivity. We used logistic regression to calculate Odds ratios (OR) for seropositivity with 95\% Cl adjusted for sex, age, and household size for participants exposed to COVID-19 infected patients within the household. Data on population and areal by municipality for 2020 was obtained from Statistics Denmark (22). For participants with previous positive PCR test, we calculated the proportion of seropositive participants. Further, we analyzed the seroprevalence according to self-assed risk of being infected with SARS-CoV-2. Demographics were compared for responders and non-responders to the questionnaire. Further, demographics were compared for participants who provided the POCT results versus participants who did not provide the POCT results. $\mathrm{P}<0.05$ was considered statistically significant. Data management, statistical analyses, and figures were performed and created using $R$ version 3.2.1 (23).

\section{Results}

\section{Baseline variables and association with seropositivity}

In total, 474,411 participants (36.5\% of invitees) replied to the electronic questionnaire and 397,843 received a POCT between October 2 and October 11, 2020. Invited persons who did not answer the questionnaire were more often males with lower participation among persons aged $<35$ and $>74$ years of age with no noticeable geographical variations (Supplementary table 1). Participants not providing POCT results were more often younger with no noticeable geographical variations (Supplementary table 1). The final study population comprised 318,552 participants (24.5\% invitees) who answered the questionnaire and provided the results of the POCT (Figure 1). Age and sex distribution of the study population are shown in Supplementary figure 1.

A total of 2,519 / 318,552 (0.79\%) participants tested seropositive with $852(0.27 \%)$ participants being positive for IgG antibodies, $1,078(0.34 \%)$ for IgM antibodies, and $589(0.18 \%)$ positive for both IgG and IgM antibodies. The seroprevalence increased with age with a higher proportion of IgM positive compared to 
medRxiv preprint doi: https://doi.org/10.1101/2021.08.10.21261777; this version posted August 13, 2021. The copyright holder for this preprint (which was not certified by peer review) is the author/funder, who has granted medRxiv a license to display the preprint in It is made available under a CC-BY-ND 4.0 International license .

150 IgG positive (age group 15-30: $0.24 \%$ IgG positive, $0.26 \%$ IgM positive, age group $>61-75: 0.25 \% \lg G$ 151 positive, $0.38 \%$ IgM positive, Supplementary figure 2). No clear difference was found between IgG and IgM 152 according to age groups (data not shown). For $\lg , 9,294$ (2.92\%) and for $\operatorname{lgM} 9,269$ (2.91\%) were 153 inconclusive, respectively.

154 Women were more likely to be seropositive (Table 1 and Supplementary figure 3). The comorbidity burden 155 was higher in seropositive participants and reached statistical significance for participants with 156 hypertension, stroke, diabetes, and chronic obstructive pulmonary disease (COPD). There was a numerically 157 higher proportion of seropositive females among participants smoking $>10$ cigarettes per day and among 158 participants consuming $>21$ standard drinks of alcohol per week. For body-mass index (BMI), the proportion 159 of seropositive females was higher in the category underweight or obese, see Supplementary figure 4.

\section{POCT findings in participants with previous COVID-19, or a positive PCR}

161 When comparing self-estimated risk of infection with POCT results, only $0.5 \%$ of participants who self162 estimated no prior infection were seropositive. Contrary, $13.5 \%$ of participants, who thought they had 163 been infected, were seropositive. In comparison, $29.1 \%$ of participants, who had previously tested positive 164 on a PCR test were seropositive (Supplementary figure 5 and Supplementary figure 6). For time between 165 positive PCR test and POCT, 37.7 \% were seropositive 21-30 days after the PCR test. The proportion of 166 seropositive participants decreased with increasing time between PCR test and POCT (Supplementary 167 figure 7). Differences between seropositive and seronegative who had previously tested positive on PCR 168 test are shown in Table 3. Notably, time between positive PCR and POCT was lower for seropositive than 169 seronegative participants.

170 Supplementary figure 8 and 9 shows geographical variations between municipalities in seropositivity and 171 variations in population density. When ordering municipalities according to population density, no clear 172 association between seropositivity and population density was found.

\section{Risk factors for seropositivity}

Protective effect of authority recommendations

175 Most participants followed multiple recommended public health measures to prevent infection, e.g. $>80 \%$ 176 reported use of face masks. However, when examining serostatus according to behavior, no difference in 177 serostatus was found between individual protective health measures, e.g. $82.5 \%$ of seronegative and $84 \%$ 178 of seropositive reported use of face masks. (Figure 2). 
medRxiv preprint doi: https://doi.org/10.1101/2021.08.10.21261777; this version posted August 13, 2021. The copyright holder for this preprint (which was not certified by peer review) is the author/funder, who has granted medRxiv a license to display the preprint in It is made available under a CC-BY-ND 4.0 International license.

180 Participants who had physical contact or lived in a household with a SARS-CoV-2 infected person had the 181 highest risk of being seropositive compared to participants who reported not to have been exposed to a 182 SARS-CoV-2 infected person; RR of 7.43 (95\% Cl: 6.57 to 8.41 ) and 17.70 (95\% Cl: 15.60 to 20.10), 183 respectively (Figure 3). Among participants exposed to a SARS-CoV-2 infected person within the household, 184 the proportion of seropositive participants was higher in smaller household sizes (see Supplementary figure 185 10). However, when adjusting for sex, age, and household size, there was no significant increased risk for 186 lower household size and risk of seropositivity (Table 2).

Occupation

188 Among professionals (full-time, part-time, and self-employed), working in the healthcare sector or with 189 home care was associated with a higher risk of seropositivity compared to office work; healthcare sector: 190 RR 2.02 (95\%Cl: 1.75 to 2.33 ), home care: RR 2.09 (95\% Cl: 1.58 to 2.78 ), see Figure 4.

\section{Symptoms}

For individual symptoms, loss of taste and smell were associated with the highest risk of being seropositive: ageusia (RR 5.91, 95\% Cl: 5.41 to 6.46) and anosmia (RR 4.84, 95\% $\mathrm{Cl}: 4.43$ to 5.29). The risk of seropositivity for each symptom is shown in Figure 5.

Participants in advanced age groups had experienced less symptoms compared to participants in younger age groups with $39.5 \%$ in age group $>75$ years compared to $8.2 \%$ in the age group $15-30$ years experiencing no symptoms (Supplementary figure 11). Further, participants in advanced age groups had been tested fewer times compared to participants in younger age groups irrespective of sex (Supplementary figure 12).

\section{Discussion}

201 To our knowledge this is the largest population-based SARS-CoV-2 surveillance study performed. The main 202 findings can be summarized as follows; females were found to have a higher seroprevalence than males. 203 Elderly participants were more often seropositive despite fewer symptoms and less often PCR tests. The 204 geographical variation in seroprevalence was limited and did not seem to be related to population density. 205 A prevalence of SARS-CoV-2 antibodies of only $0.79 \%$ was reported. Only $29 \%$ of PCR positive were POCT seropositive in our study. The study showed a high degree of adherence with national recommendation but there was no clear difference in reported compliance between seropositive and seronegative participants 
medRxiv preprint doi: https://doi.org/10.1101/2021.08.10.21261777; this version posted August 13, 2021. The copyright holder for this preprint (which was not certified by peer review) is the author/funder, who has granted medRxiv a license to display the preprint in It is made available under a CC-BY-ND 4.0 International license.

208 in the study period which covered the interval between the first infectious wave in spring 2020 and the 209 second in autumn/winter.

Age and sex

211 Until October 2020, 2.4 million people in Denmark had been tested with PCR at least once and up to 212 multiple times, and 27,998 people were confirmed PCR positive ( $0.5 \%$ of the total population) (24). A 213 population-based study in Denmark with 7,015 participants from August 2020 found a seroprevalence of $2142.0 \%$ (age > 12 years) measured by Wantai SARS-CoV-2 Ab ELISA (10), the point estimates tended to be 215 higher in the age group 18-39 years and lower in the age group $>65$ years, with no difference observed by 216 sex. Also, a convenience sample of blood donors tested in October 2020 with ELISA found a seroprevalence 217 of $2.1 \%$ (adults aged $18-70$ ) (25). In contrast, we found a seroprevalence of only $0.79 \%$, higher proportions of seropositivity in younger age groups and females being seropositive more often.

A Danish study of household transmission, with individual level register data on all national PCR test for SARS-CoV-2 for the period February-July 2020, suggested that susceptibility to infection increases with the age of the susceptible person (26). Other international studies tends to show trends in line with our results with an increase in seropositivity with age (9) and females having increased IgG positivity (27). By sending our test material to participants at home, we may have been able to include vulnerable and elderly susceptible to infection who otherwise would not have had the opportunity to participate. This is supported by our findings that participation in POCT was high in all age groups except the younger age group. This could partially explain the difference in seroprevalence between our study and aforementioned Danish studies, which included healthy blood donors as well as a population that should attend a venous blood sample.

In Denmark, one of the measures to contain the epidemic has been to offer easy-access, free of charge testing. The Danish Health authorities have encouraged the population to have test performed in case of symptoms of COVID-19 or after close contact with infected persons. Elderly participants reported fewer previous tests. When compared to younger participants, elderly participants might have fewer social contacts and/or could have isolated themselves to a higher degree thus avoiding potential close contact with infected persons. Further, younger participants may be more exposed to infection by having more social contacts or via their employment. However, in a recent report by the HOPE project (How Democracies Cope with COVID19), elderly people in Denmark were not found to report higher levels of self- 
medRxiv preprint doi: https://doi.org/10.1101/2021.08.10.21261777; this version posted August 13, 2021. The copyright holder for this preprint (which was not certified by peer review) is the author/funder, who has granted medRxiv a license to display the preprint in It is made available under a CC-BY-ND 4.0 International license.

quarantine when experiencing symptoms or when testing positive by PCR compared to younger people (28).

The strongest correlation to seropositivity was ageusia and anosmia (loss of taste and smell), consistent with previous findings $(15,16,18)$. In general, we found that seropositive participants more frequently recalled having had symptoms when compared to seronegative participants.

When stratifying for age groups, elderly participants reported symptoms less frequently. It may be that only the healthiest elderly participated, however, this outcome could also be a bias resulting from comorbidity disorders and long recall period. Our results are surprising because aging itself has been associated with more severe COVID-19 symptoms due to increased comorbidities with age and more aggressive clinical behavior (29). Nevertheless, the level of antibodies (comparable levels of IgG and IgM) was highest among elderly participants although they reported fewer symptoms and had fewer tests. As such, elderly participants may more often be subject to asymptomatic infections, thereby constituting an important subgroup that may warrant further attention. However, it should also be noted that individuals in the working age who were unable to work from home may attend PCR testing more often than people who have retired, and this could contribute to our observations.

\section{Occupation}

As previously reported, working in the health care sector was associated with a higher risk of seropositivity $(16,30)$. Working in home care or at nursing homes also increased the risk. These occupations often involves working with patients and being in close physical contact to other persons, thus increasing the risk of infection (30). The proportion of females working in the health care sector is typically higher than males (31), possibly explaining the higher proportion of seropositive females. Conversely, those who have office jobs, and therefor possibly better opportunities to work from home, have been at less risk of infection during the first infectious surge.

\section{Behavior and household}

We observed a high proportion of participants following the authority's recommendations to reduce the risk of SARS-CoV-2 infection. Remarkably, seropositive participants were slightly more compliant with these recommendations compared to seronegative participants on almost all the preventive measures. However, participants who are more attentive to recommendations, e.g. health care professionals are more exposed to SARS-CoV-2 infection. As such, the effect of the authority's recommendations could be underestimated. Household composition is an important venues for transmission of infection due to household size and living conditions (32). Sustained close contact and crowded indoor environments pose a higher risk of 
medRxiv preprint doi: https://doi.org/10.1101/2021.08.10.21261777; this version posted August 13, 2021. The copyright holder for this preprint (which was not certified by peer review) is the author/funder, who has granted medRxiv a license to display the preprint in It is made available under a CC-BY-ND 4.0 International license.

269 transmission $(33,34)$. A metanalysis by Madewell et al indicated that household and family members are at 270 higher risk of infection compared with other types of close contacts, and spouses were at higher risk 271 compared with family contacts. Further, household crowding (e.g. number of people per room) may be 272 more important for transmission than the total number of people per household (32). Our results showed 273 seropositivity to be highest among smaller households with only two household members, possibly due to 274 two person households often comprising of couples with close contact, and thereby increased risk of 275 transmission. This finding is also consistent with a previous preprint study on SARS-CoV-2 transmission 276 within Danish households, which demonstrated a transmission pattern that was exponentially decreasing 277 with the number of members in the household (26).

Strengths and limitations

279 This population-based study had a broad national participation with $22 \%$ of the population invited and a response rate of $36.5 \%$ among the invitees for the questionnaire and $24.5 \%$ for the POCT. To determine the distribution of infectious disease, serological surveys with a representative sample of the wider population are important, particularly in the presence of asymptomatic individuals or incomplete ascertainment of those with symptoms.

This study has limitations. Recruitment of participants by e-Boks might exclude the proportion of the population that are without or have only limited access to this digital governmental information system and less technology-proficient individuals, or marginalized groups who are seen to have a higher risk of infection $(17,18)$. A smaller proportion of residents may not have been able to read and understand Danish, English or Arabic. People under the age of 15 years were not included and the findings are not applicable to children. Data on ethnicity was not available from the questionnaire. The recall period of symptoms was long, up to 7 months. Information on the exact point of time for participants becoming infected or turning seropositive was not available. In addition, persons with a previous positive PCR may have been less inclined to participate, thereby resulting in selection bias and potentially underestimating the true seroprevalence. Conversely, particularly persons working in health care or nursing may have had an increased interest to know about possible protective immune status due to their working tasks and knowledge of former infection and/or increased exposure.

The low seroprevalence at $0.79 \%$ in our study may be due to low sensitivity of the POCT used or due to challenges relating to the reading of the test results, since $2.9 \%$ were inconclusive. POCT in general have a lower diagnostic performance compared to laboratory testing (35). Test results also depend on the prevalence of infection in the population which will be low when screening asymptomatic and higher for those with suggestive symptoms. In low prevalence settings, true positive test results are uncommon. As 
medRxiv preprint doi: https://doi.org/10.1101/2021.08.10.21261777; this version posted August 13, 2021. The copyright holder for this preprint (which was not certified by peer review) is the author/funder, who has granted medRxiv a license to display the preprint in It is made available under a CC-BY-ND 4.0 International license .

such, the predictive value of a positive test will be lower in individuals with a low background risk of infection (36). Only $0.5 \%$ of the Danish population were confirmed PCR positive during the study period. The diagnostic testing window is also of importance as the study was performed seven to eight months after the first COVID-19 case in Denmark. The antibody response of IgM and IgG is found to be highest about 2-3 weeks and 3-4 weeks, respectively after symptom onset and decrease afterwards (35). 37\% of our study participants had a positive POCT 20-30 days after a positive PCR. In addition, we found that for seronegative, longer time had passed from a previously positive PCR test than for seropositive. As participants performed the POCT at home, incorrect testing procedure or misinterpreted POCT results could lead to false negative POCT results. Importantly, inconclusive tests were treated as negative in our study, and weak lines suggesting a positive test result, could be misinterpreted as a negative test result. In other Danish studies, the tests (POCT and ELISA) have been performed and read or analyzed by professional staff which increases the performance of the test. Consequently, the seroprevalence is likely underestimated in our study. However, seropositivity was low among participants who did not have a previous positive PCR test, indicating a high specificity of the POCT, thus the associations found are reliable.

\section{Perspectives}

To date, this is the largest population-based Danish study where test material has been sent to participants and performed at home with broad national participation. Nationwide information can be difficult to gather and the study design in question presents a novel way for conducting future studies. Additionally, this setup can be used as a model for ongoing monitoring of COVID-19 immunity in the population, both from past infection and from vaccination against SARS-CoV-2.

\section{Conclusion}

This study provides insight into the immunity of the Danish population seven to eight months after the first COVID-19 case in Denmark. The seroprevalence was lower than expected probably due to low sensitivity of the POCT used or due to challenges relating to the reading of test results. Future studies could be improved with an easier POCT test to perform and a shorter questionnaire. A high degree of compliance with national preventive recommendations was seen, but no clinically significant protective effect was identified. Occupation, domestic exposure and other known exposures in the local communities were clear routes of infection, and in particular transmission in two person households, served as a major domain of transmission. As elderly participants were more often seropositive despite fewer symptoms and less testing, more emphasis should be placed on testing this age group. 
medRxiv preprint doi: https://doi.org/10.1101/2021.08.10.21261777; this version posted August 13, 2021. The copyright holder for this preprint (which was not certified by peer review) is the author/funder, who has granted medRxiv a license to display the preprint in It is made available under a CC-BY-ND 4.0 International license .

332

333

\section{Funding}

This study was supported by grants from the Danish Ministry of Health (2012461). The funders did not influence study design, conduct, or reporting.

\section{Contributors}

The study was designed and initiated by: KF, BS, RS, HU and KI.

Data analysis was done by: JS and KF

The first draft was written by: KF, JS, HB, RS and KI

All authors have critically revised the manuscript and agree to be accountable for all aspects of the work.

All authors approved the final version of the manuscript.

\section{Declaration of interests}

The authors declared no potential conflict of interest with respect to the research, authorship, and/or publication of this article.

\section{Acknowledgements}

The authors would like to thank the Danish Ministry of Health, the Danish Patient Safety Authority, the Local Government Denmark, Danish Regions, Danish Patients, DaneAge Association, the Danish Medical Association, the Danish Nurses Organization, the Danish Heart Association, the Danish Cancer Society, the Danish Lung Association, the Danish National Organization for homeless people (SAND), the Danish Family Planning Association and the Council for Ethnic Minorities for support of the study. 
medRxiv preprint doi: https://doi.org/10.1101/2021.08.10.21261777; this version posted August 13, 2021. The copyright holder for this preprint (which was not certified by peer review) is the author/funder, who has granted medRxiv a license to display the preprint in

It is made available under a CC-BY-ND 4.0 International license .

\section{References}

1. Aziz NA, Corman VM, Echterhoff AKC, Müller MA, Richter A, Schmandke A, et al. Seroprevalence and correlates of SARS-CoV-2 neutralizing antibodies from a population-based study in Bonn, Germany. Nat Commun. 2021;12(1):2117.

2. Oran DP, Topol EJ. Prevalence of Asymptomatic SARS-CoV-2 Infection : A Narrative Review. Ann Intern Med. 2020;173(5):362-7.

3. Koopmans M, Haagmans B. Assessing the extent of SARS-CoV-2 circulation through serological studies. Nat Med. 2020;26(8):1171-2.

4. Rostami A, Sepidarkish M, Leeflang MMG, Riahi SM, Nourollahpour Shiadeh M, Esfandyari S, et al. SARS-CoV-2 seroprevalence worldwide: a systematic review and meta-analysis. Clin Microbiol Infect. 2021;27(3):331-40.

5. McConnell D, Hickey C, Bargary N, Trela-Larsen L, Walsh C, Barry M, et al. Understanding the Challenges and Uncertainties of Seroprevalence Studies for SARS-CoV-2. Int J Environ Res Public Health. 2021;18(9).

6. Danmarks statistik. Folketal. 2021, may 12 [Available from:

https://www.dst.dk/da/Statistik/emner/befolkning-og-valg/befolkning-ogbefolkningsfremskrivning/folketal.

7. The Danish Health Authority. Current data on the development of coronavirus. 2021, April 29 [Available from: https://www.sst.dk/en/English/Corona-eng/Status-of-the-epidemic/COVID-19-updatesStatistics-and-charts.

8. $\quad$ Statens Serum Institut. COVID-19 - Epidemiologisk overvågningsrapport. 29 March 2020. [Available from: https://www.ssi.dk/sygdomme-beredskab-og-forskning/sygdomsovervaagning/c/covid19overvaagning/arkiv-med-overvaagningsdata-for-covid19.

9. Grant R, Dub T, Andrianou X, Nohynek H, Wilder-Smith A, Pezzotti P, et al. SARS-CoV-2 population-based seroprevalence studies in Europe: a scoping review. BMJ Open. 2021;11(4):e045425. 10. $\quad$ Espenhain L, Tribler S, Jørgensen CS, Holm Hansen C, Wolff Sönksen U, Ethelberg S. Prevalence of SARS-CoV-2 antibodies in Denmark 2020: results from nationwide, population-based seroepidemiological surveys. medRxiv. 2021:2021.04.07.21254703.

11. Pottegard A, Kristensen KB, Reilev M, Lund LC, Ernst MT, Hallas J, et al. Existing Data Sources in Clinical Epidemiology: The Danish COVID-19 Cohort. Clin Epidemiol. 2020;12:875-81.

12. The Danish Ministry of Health. Vaccination mod COVID-19. 2021 [Available from: https://sum.dk/temaer/vaccination-mod-covid-19.

13. Karadag E. Increase in COVID-19 cases and case-fatality and case-recovery rates in Europe: A cross-temporal meta-analysis. J Med Virol. 2020;92(9):1511-7.

14. Erikstrup C, Hother CE, Pedersen OBV, Molbak K, Skov RL, Holm DK, et al. Estimation of SARSCoV-2 Infection Fatality Rate by Real-time Antibody Screening of Blood Donors. Clin Infect Dis. 2021;72(2):249-53.

15. Madsen JR, Nielsen JPS, Fogh K, Hansen CB, Nielsen PB, Lange T, et al. Anti-SARS-CoV-2 seropositivity among medical students in Copenhagen. medRxiv. 2021:2021.02.09.21251421.

16. Iversen K, Bundgaard H, Hasselbalch RB, Kristensen JH, Nielsen PB, Pries-Heje M, et al. Risk of COVID-19 in health-care workers in Denmark: an observational cohort study. Lancet Infect Dis. 2020;20(12):1401-8.

17. Eriksen ARR, Fogh K, Hasselbalch RB, Bundgaard H, Nielsen SD, Joergensen CS, et al. SARSCoV-2 antibody prevalence among homeless people, sex workers and shelter workers in Denmark: a nationwide cross-sectional study. medRxiv. 2021:2021.05.07.21256388.

18. Fogh K, Eriksen AR, Hasselbalch RB, Kristensen ES, Bundgaard H, Nielsen SD, et al. Seroprevalence of SARS-CoV-2 antibodies in social housing areas in Denmark. medRxiv. 2021:2021.05.07.21256725. 
medRxiv preprint doi: https://doi.org/10.1101/2021.08.10.21261777; this version posted August 13, 2021. The copyright holder for this preprint (which was not certified by peer review) is the author/funder, who has granted medRxiv a license to display the preprint in

It is made available under a CC-BY-ND 4.0 International license .

19. Schmidt M, Pedersen L, Sørensen HT. The Danish Civil Registration System as a tool in epidemiology. Eur J Epidemiol. 2014;29(8):541-9.

20. Institut SS. MiBa, HAIBA og det digitale infektionsberedskab 2021 [Available from:

https://miba.ssi.dk/.

$21 . \quad$ CTK Biotech inc. OnSite COVID-19 IgG/IgM Rapid Test. 2020 [Available from:

https://cdn2.hubspot.net/hubfs/4418101/PI-R0180C\%20Rev\%20B2.1.pdf.

$22 . \quad$ Danmarks Statistik. Statistikbanken. 2021. [Available from:

https://www.statistikbanken.dk/statbank5a/default.asp?w=1920.

23. Team RC. R: A Language and Eviroment for Statistical Computing. 2016 [Available from: https://www.gbif.org/tool/81287/r-a-language-and-environment-for-statistical-computing.

$24 . \quad$ Danmarks Statistik. COVID-19 - hurtige indikatorer 2021 [Available from:

https://www.dst.dk/da/Statistik/covid-19-hurtige-indikatorer.

$25 . \quad$ Blodddonorerne i Danmark. Bloddonorer testes for overstået infektion med coronavirus 2020 [Available from:

https://bloddonor.dk/coronavirus/?utm source=MarketingPlatform\&utm medium=email\&utm campaign =Nyhedsbrev+-+oktober+2020\&utm content $=72197205$.

$26 . \quad$ Lyngse FP, Kirkeby CT, Halasa T, Andreasen V, Skov RL, Møller FT, et al. COVID-19

Transmission Within Danish Households: A Nationwide Study from Lockdown to Reopening. medRxiv. 2020:2020.09.09.20191239.

27. Zeng F, Dai C, Cai P, Wang J, Xu L, Li J, et al. A comparison study of SARS-CoV-2 IgG antibody between male and female COVID-19 patients: A possible reason underlying different outcome between sex. J Med Virol. 2020;92(10):2050-4.

$28 . \quad$ HOPE project. Befolkningens selvrapporterede overholdelse af anbefalinger om selvisolation. 2020. [Available from: www.hope-project.dk.

29. Perrotta F, Corbi G, Mazzeo G, Boccia M, Aronne L, D'Agnano V, et al. COVID-19 and the elderly: insights into pathogenesis and clinical decision-making. Aging Clin Exp Res. 2020;32(8):1599-608.

30. Barrett ES, Horton DB, Roy J, Gennaro ML, Brooks A, Tischfield J, et al. Prevalence of SARSCoV-2 infection in previously undiagnosed health care workers in New Jersey, at the onset of the U.S. COVID-19 pandemic. BMC Infect Dis. 2020;20(1):853.

31. CEVEA. Det kønsopdelte arbejdsmarked. [Available from:

https://dsr.dk/sites/default/files/24/det koensopdelte arbejdsmarked cevea002.pdf.

32. Madewell ZJ, Yang Y, Longini IM, Jr., Halloran ME, Dean NE. Household Transmission of SARSCoV-2: A Systematic Review and Meta-analysis. JAMA Netw Open. 2020;3(12):e2031756.

33. Stringhini S, Wisniak A, Piumatti G, Azman AS, Lauer SA, Baysson H, et al. Seroprevalence of anti-SARS-CoV-2 IgG antibodies in Geneva, Switzerland (SEROCoV-POP): a population-based study. Lancet. 2020;396(10247):313-9.

34. Roederer T, Mollo B, Vincent C, Nikolay B, Llosa AE, Nesbitt R, et al. Seroprevalence and risk factors of exposure to COVID-19 in homeless people in Paris, France: a cross-sectional study. Lancet Public Health. 2021;6(4):e202-e9.

35. Liu G, Rusling JF. COVID-19 Antibody Tests and Their Limitations. ACS Sens. 2021;6(3):593-

612.

36.

Watson J, Richter A, Deeks J. Testing for SARS-CoV-2 antibodies. Bmj. 2020;370:m3325. 
medRxiv preprint doi: https://doi.org/10.1101/2021.08.10.21261777; this version posted August 13, 2021. The copyright holder for this preprint (which was not certified by peer review) is the author/funder, who has granted medRxiv a license to display the preprint in It is made available under a CC-BY-ND 4.0 International license .

Table 1: Baseline characteristics of the study cohort on sex, age, BMI, smoking, alcohol use, previous test result and comorbidities stratified by seropositivity.

\begin{tabular}{lrrr} 
Full cohort & Seronegative & Seropositive & $\mathbf{p}$ \\
\hline $\mathbf{n}$ & 316,033 & 2,519 & 0.041 \\
Age (years) (median [IQR]) & $53[39-64])$ & $55[42-64]$ & $<0.001$ \\
Male (\%) & $113,412(42.2)$ & $1,012(40.2)$ & 0.115 \\
Body mass index (median [IQR]) & $25.4[22.8,28.7]$ & $25.5[23,29]$ & 0.161 \\
Ever smoker (\%) & $168,024(53.2)$ & $1,375(54.6)$ & 0.443 \\
Alcohol use* (\%) & $36,747(12.9)$ & $302(13.5)$ & \\
Comorbidities (\%) & & & 0.389 \\
$\quad$ Myocardial infarction & $6562(2.1)$ & $59(2.3)$ & 0.030 \\
Stroke & $9067(2.9)$ & $91(3.6)$ & 0.013 \\
Hypertension & $82215(26.0)$ & $711(28.2)$ & $165(6.6)$ \\
$\quad$ Diabetes & $17528(5.5)$ & $185(7.3)$ & 1.0032 \\
Cancer & $23250(7.4)$ & $176(7.0)$ & 0.074 \\
Rheumatoid arthritis & $19309(6.1)$ & $150(6.0)$ & $<0.001$ \\
COPD & $13872(4.4)$ & $375(14.9)$ & 0.172 \\
$\quad$ Asthma & $43996(13.9)$ & $456(18.1)$
\end{tabular}

${ }^{*}$ Alcohol use: Reporting $>7$ units of alcohol a week for females or $>14$ units of alcohol for males 
medRxiv preprint doi: https://doi.org/10.1101/2021.08.10.21261777; this version posted August 13, 2021. The copyright holder for this preprint (which was not certified by peer review) is the author/funder, who has granted medRxiv a license to display the preprint in It is made available under a CC-BY-ND 4.0 International license.

Table 2: Odds ratio for age, sex and household size stratified by seropositivity of the cohort

\begin{tabular}{lllll} 
Variable & & Odds Ratio & $\mathbf{9 5 \%} \mathbf{C l}$ & p-value \\
\hline Age & & 1.02 & {$[1.01 ; 1.03]$} & $<0.001$ \\
Male & 1.01 & {$[0.77 ; 1.34]$} & 0.920 \\
Household & 2 & Ref & & \\
& 3 & 0.75 & {$[0.51 ; 1.09]$} & 0.128 \\
& 4 & 0.73 & {$[0.50 ; 1.07]$} & 0.106 \\
& 5 & 0.58 & {$[0.34 ; 1.01]$} & 0.054 \\
& $>5$ & 0.59 & {$[0.30 ; 1.16]$} & 0.127
\end{tabular}


medRxiv preprint doi: https://doi.org/10.1101/2021.08.10.21261777; this version posted August 13, 2021. The copyright holder for this preprint (which was not certified by peer review) is the author/funder, who has granted medRxiv a license to display the preprint in It is made available under a CC-BY-ND 4.0 International license .

Table 3: Characteristics of the study cohort who previously testes positive on PCR test.

\begin{tabular}{|c|c|c|c|c|}
\hline Full cohort & Seronegative & Seropositive & Total & $\mathbf{p}$ \\
\hline $\mathbf{n}$ & 1,296 & 532 & 1,828 & \\
\hline Age (years) (median [IQR]) & $47[31-59])$ & $51[40-61]$ & 49 [34-59] & $<0.001$ \\
\hline Male (\%) & $480(37.0)$ & $233(43.8)$ & $713(39.0)$ & 0.008 \\
\hline Body mass index (median [IQR]) & $24.9[22.4,28.4]$ & $25.6[23.0,29.1]$ & $25.1[22.6,28.7]$ & 0.003 \\
\hline $\begin{array}{l}\text { Days between pos. PCR and POCT } \\
\text { (median [IQR]) }\end{array}$ & $58[26,188]$ & $38[23,176]$ & $46.5[25,187]$ & 0.082 \\
\hline missing & 693 & 331 & 1,024 & \\
\hline \multicolumn{5}{|l|}{ Comorbidities (\%) } \\
\hline Myocardial infarction & $26(2.0)$ & $11(2.1)$ & $37(2.0)$ & 1.000 \\
\hline Stroke & $31(2.4)$ & $17(3.2)$ & $48(2.6)$ & 0.415 \\
\hline Hypertension & $257(19.8)$ & $129(24.2)$ & $386(21.1)$ & 0.041 \\
\hline Diabetes & $67(5.2)$ & $38(7.1)$ & $105(5.7)$ & 0.124 \\
\hline Cancer & $75(5.8)$ & $33(6.2)$ & 108 (5.9) & 0.815 \\
\hline Rheumatoid arthritis & $72(5.6)$ & $31(5.8)$ & $103(5.6)$ & 0.907 \\
\hline COPD & $46(3.5)$ & $21(3.9)$ & $67(3.7)$ & 0.784 \\
\hline Asthma & $202(15.6)$ & $84(15.8)$ & $286(15.6)$ & 0.970 \\
\hline Other chronic disease & $211(16.3)$ & $84(15.8)$ & $295(16.1)$ & 0.850 \\
\hline Alcohol use* (\%) & $144(12.5)$ & $56(11.7)$ & $22(12.3)$ & 0.708 \\
\hline Ever smoker (\%) & $607(46.8)$ & $278(52.3)$ & $885(48.4)$ & 0.040 \\
\hline
\end{tabular}


medRxiv preprint doi: https://doi.org/10.1101/2021.08.10.21261777; this version posted August 13, 2021. The copyright holder for this preprint (which was not certified by peer review) is the author/funder, who has granted medRxiv a license to display the preprint in It is made available under a CC-BY-ND 4.0 International license.

\section{Figure Legends}

Figure 1: CONSORT diagram.

Figure 2: Proportion of participants following public health measures stratified for serostatus among 318,552 individuals.

Figure 3: Risk ratio for seropositivity in a subset of 32,812 participants exposed to COVID-19 infected persons in various settings. For each setting, participants exposed to COVID-19 infected persons was compared to participants not exposed in this setting (reference group).

Figure 4: Risk ratio for seropositivity in a subset of 193,646 working (full-time, part-time, or self-employed) participants. Participants in each profession were compared to participants in office work.

Figure 5: Risk of seropositivity for individual symptoms. Analysis included 318,552 participants. 
medRxiv preprint doi: https://doi.org/10.1101/2021.08.10.21261777; this version posted August 13, 2021. The copyright holder for this preprint (which was not certified by peer review) is the author/funder, who has granted medRxiv a license to display the preprint in It is made available under a CC-BY-ND 4.0 International license .

Figure 1: CONSORT diagram

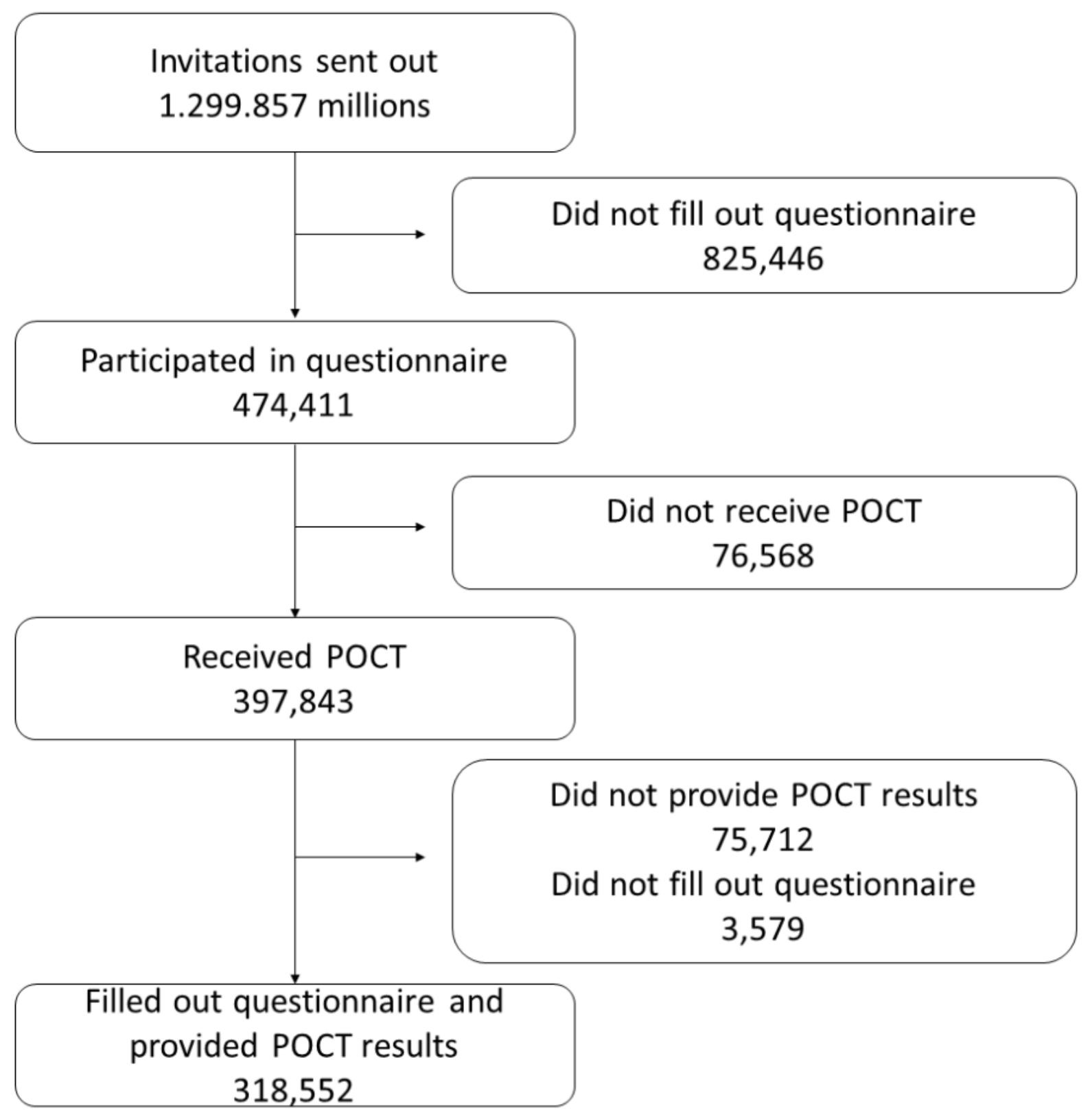


medRxiv preprint doi: https://doi.org/10.1101/2021.08.10.21261777; this version posted August 13, 2021. The copyright holder for this preprint (which was not certified by peer review) is the author/funder, who has granted medRxiv a license to display the preprint in It is made available under a CC-BY-ND 4.0 International license .

Figure 2: Proportion of participants following public health measures stratified for serostatus among 318,552 individuals.

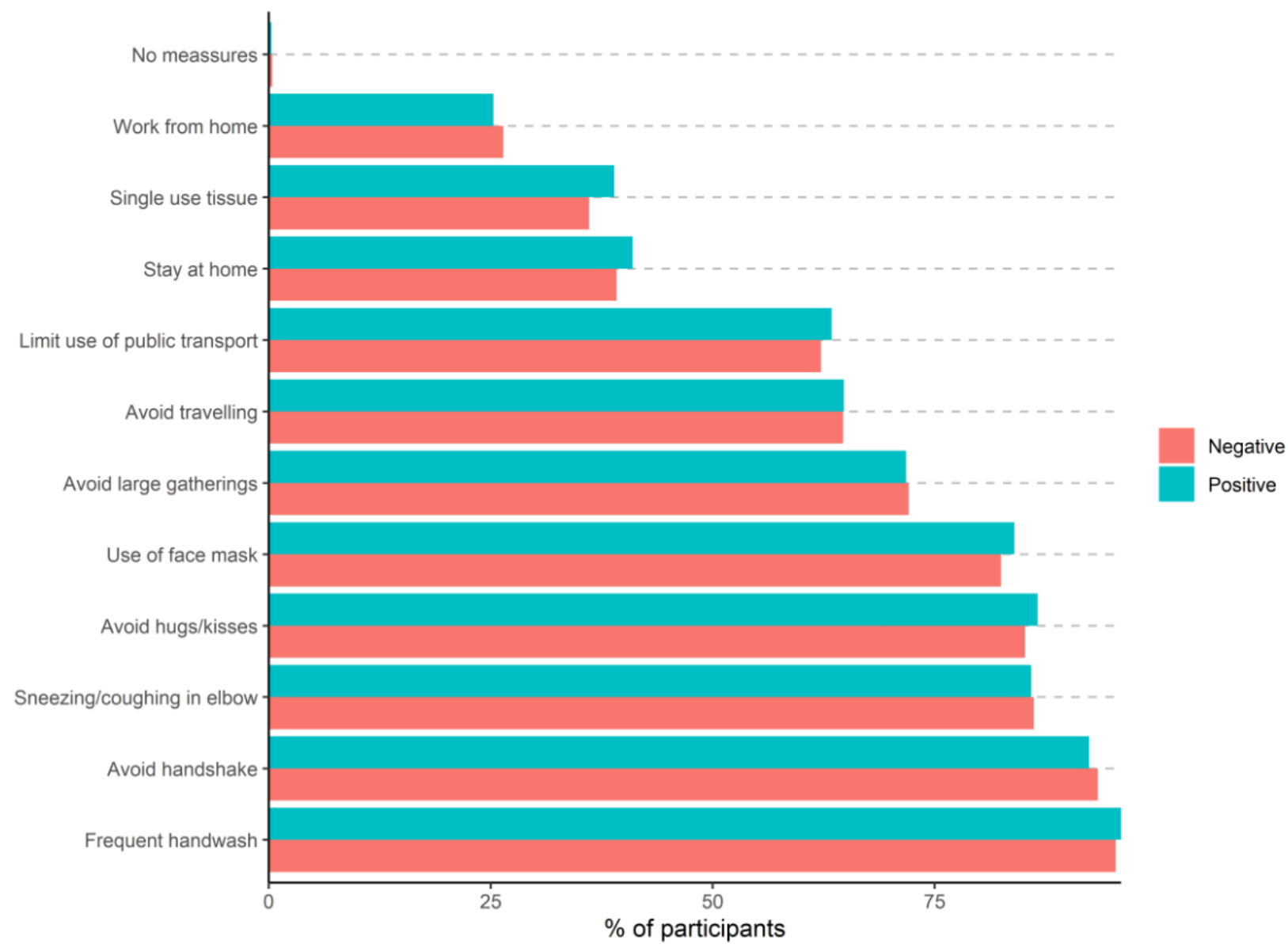


medRxiv preprint doi: https://doi.org/10.1101/2021.08.10.21261777; this version posted August 13, 2021. The copyright holder for this preprint (which was not certified by peer review) is the author/funder, who has granted medRxiv a license to display the preprint in It is made available under a CC-BY-ND 4.0 International license.

Figure 3: Risk ratio for seropositivity in a subset of 32,812 participants exposed to COVID-19 infected persons in various settings. For each setting, participants exposed to COVID-19 infected persons was compared to participants not exposed in this setting (reference group).

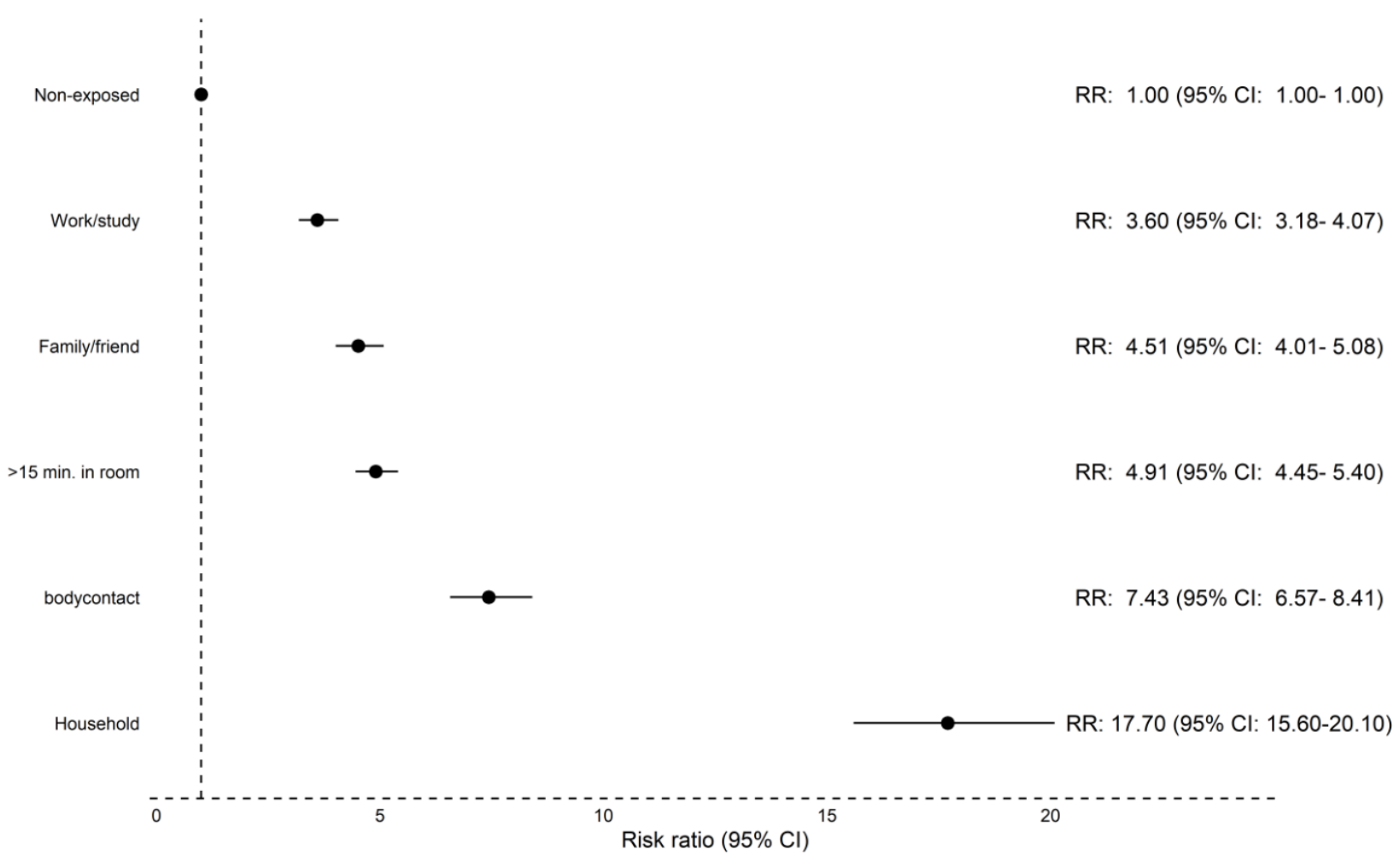


medRxiv preprint doi: https://doi.org/10.1101/2021.08.10.21261777; this version posted August 13, 2021. The copyright holder for this preprint (which was not certified by peer review) is the author/funder, who has granted medRxiv a license to display the preprint in

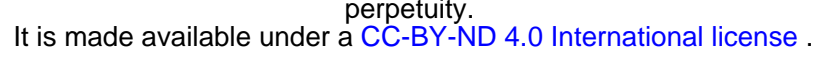

Figure 4: Risk ratio for seropositivity in a subset of 193,646 working (full-time, part-time, or self-employed) participants. Participants in each profession were compared to participants in office work.

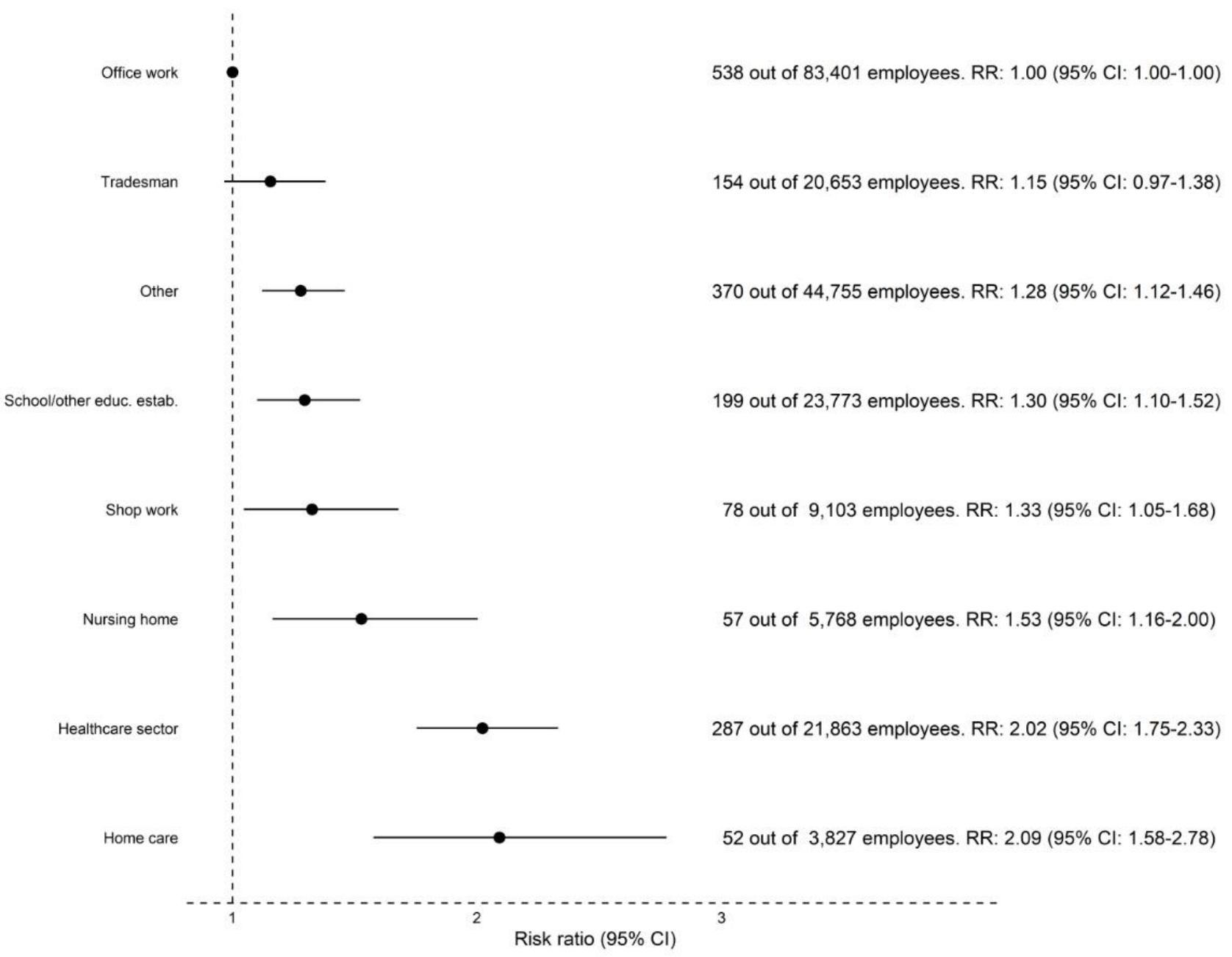


medRxiv preprint doi: https://doi.org/10.1101/2021.08.10.21261777; this version posted August 13, 2021. The copyright holder for this preprint (which was not certified by peer review) is the author/funder, who has granted medRxiv a license to display the preprint in It is made available under a CC-BY-ND 4.0 International license .

Figure 5: Risk of seropositivity for individual symptoms. Analysis included 318,552 participants.

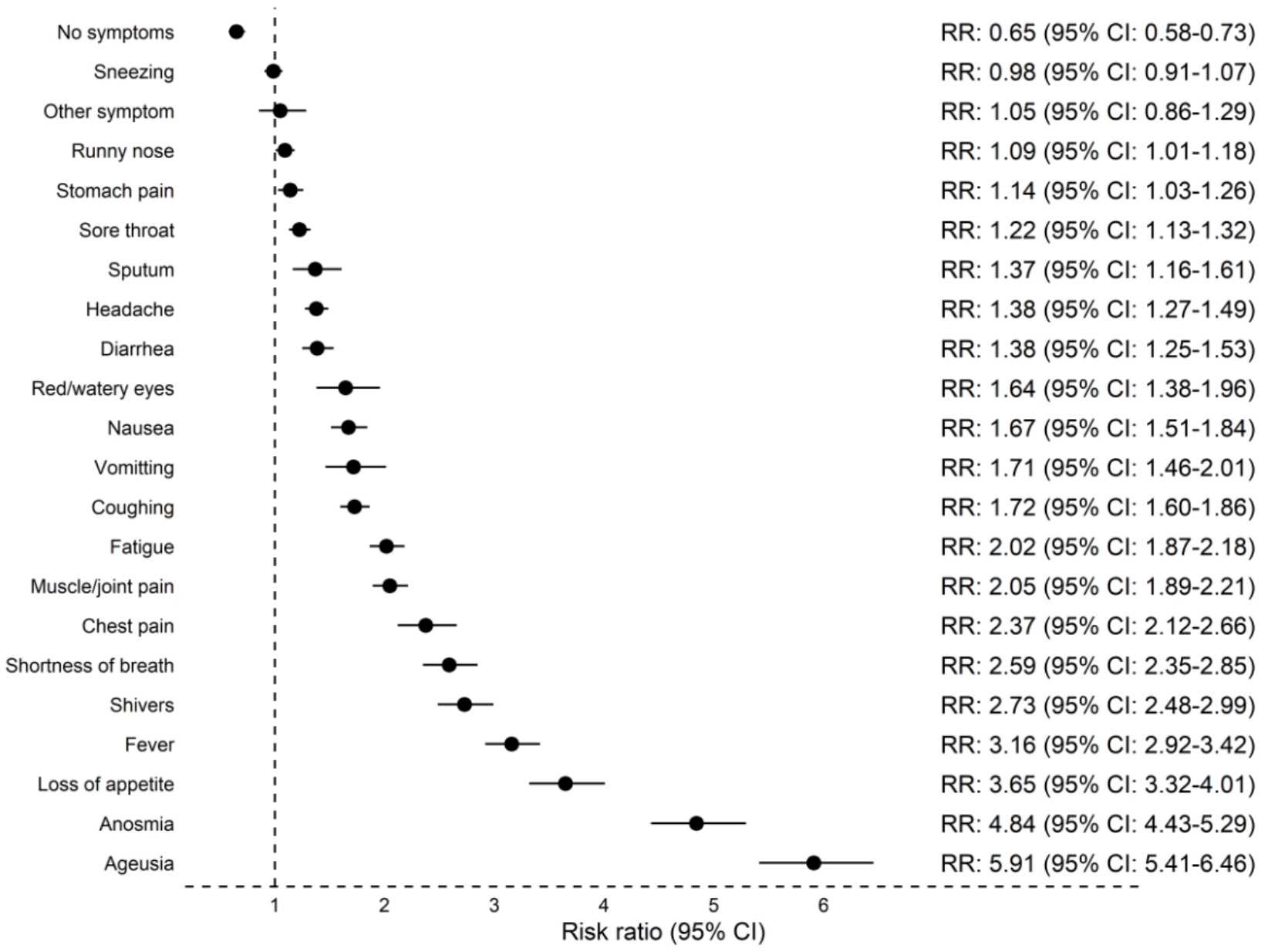


medRxiv preprint doi: https://doi.org/10.1101/2021.08.10.21261777; this version posted August 13, 2021. The copyright holder for this preprint (which was not certified by peer review) is the author/funder, who has granted medRxiv a license to display the preprint in It is made available under a CC-BY-ND 4.0 International license .

\section{Supplementary materials:}

Supplementary table 1: Sex and age group distribution and place of living for responders and nonresponders among population invited to participate in the questionnaire. Missing data represents invited persons who requested to be removed. Also shown are sex and age group distribution and place of living for participants who provided POCT results versus participants who did not provide the POCT results.

Supplementary figure 1: Age and sex distribution of the final study population. Numbers above bars represent number of participants in each group.

Supplementary figure 2: Distribution of SARS-CoV-2 antibodies according to age groups. Numbers above bars represent percentage of total number of participants in groups.

Supplementary figure 3: SARS-CoV-2 seropositive $\%$ among 318,552 individuals stratified for age groups and sex. Numbers above bars represent total of participants within each group.

Supplementary figure 4: SARS-CoV-2 seropositive \% according to smoking habits, weekly alcohol consumption, and BMI stratified for sex. Red bar represents females, blue bar represents males. Numbers above bars represent number of participants in each group.

Supplementary figure 5: Seropositive \% for self-assed risk of being infected and seropositive \% for participants with a previous positive PCR test. Purple bar represents a subset of 1,828 participants with a positive PCR test prior to POCT test. Red, green, and blue bars represent participants without a prior positive PCR test. The self-assed risk of being infected was compared to the result of POCT test

Supplementary figure 6: Flowchart for identifying participants with a positive PCR test before POCT.

Supplementary figure 7: SARS-Cov-2 seropositive $\%$ among 804 individuals by POCT stratified for days since positive PCR.

Supplementary figure 8: Map of seropositivity for each municipality.

Supplementary figure 9: Scatterplot of seropositive \% according to population density for all municipalities. Each $x$-axis tick represents a municipality with the corresponding population density. Dots, triangles, squares, and crosses represent population density quartiles from lowest to highest quartile, respectively.

Supplementary figure 10: SARS-CoV-2 seropositive \% in households with a COVID-19 infected person stratified by household size. Numbers above bars represent number of seropositive and seronegative participants in each household size.

Supplementary figure 11: Proportion of persons who experienced symptoms stratified for age groups. Numbers next to bars represent percentages.

Supplementary figure 12: Number of previous tests for 318,552 participants stratified for age groups and sex. 
medRxiv preprint doi: https://doi.org/10.1101/2021.08.10.21261777; this version posted August 13, 2021. The copyright holder for this preprint (which was not certified by peer review) is the author/funder, who has granted medRxiv a license to display the preprint in

It is made available under a CC-BY-ND 4.0 International license .

Supplementary table 1: Sex and age group distribution and place of living for responders and nonresponders among population invited to participate in the questionnaire. Missing data represents invited persons who requested to be removed. Also shown are sex and age group distribution and place of living for participants who provided POCT results versus participants who did not provide the POCT results. Col: Column, POCT: Point of care test

\begin{tabular}{|c|c|c|c|c|c|c|}
\hline \multirow[b]{2}{*}{$\begin{array}{l}\mathbf{N} \\
\text { Row \% } \\
\text { Col \% } \\
\end{array}$} & \multicolumn{3}{|c|}{ Answered Questionnaire } & \multicolumn{3}{|c|}{ Provided POCT result } \\
\hline & No & Yes & Total & No & Yes & Total \\
\hline Females & $\begin{array}{l}384,507 \\
58.6 \% \\
46.6 \% \\
\end{array}$ & $\begin{array}{l}272,012 \\
41.4 \% \\
57.3 \% \\
\end{array}$ & $\begin{array}{l}656,519 \\
50.5 \%\end{array}$ & $\begin{array}{l}43,538 \\
18.9 \% \\
54.4 \% \\
\end{array}$ & $\begin{array}{l}186,342 \\
81.1 \% \\
57.9 \% \\
\end{array}$ & $\begin{array}{l}229,880 \\
57.2 \%\end{array}$ \\
\hline Males & $\begin{array}{l}440,939 \\
68.5 \% \\
53.4 \% \\
\end{array}$ & $\begin{array}{l}202,399 \\
31.6 \% \\
42.8 \% \\
\end{array}$ & $\begin{array}{l}643,338 \\
49.5 \%\end{array}$ & $\begin{array}{l}36,433 \\
21.2 \% \\
45.6 \% \\
\end{array}$ & $\begin{array}{l}135,789 \\
78.9 \% \\
42.2 \% \\
\end{array}$ & $\begin{array}{l}172,222 \\
42.8 \%\end{array}$ \\
\hline Total & $\begin{array}{l}825,446 \\
63.5 \%\end{array}$ & $\begin{array}{l}474,411 \\
36.5 \%\end{array}$ & $\begin{array}{l}1,299,857 \\
100.00\end{array}$ & $\begin{array}{l}79,971 \\
19.9 \%\end{array}$ & $\begin{array}{l}322,131 \\
80.1 \%\end{array}$ & $\begin{array}{l}402,102 \\
100 \%\end{array}$ \\
\hline $\begin{array}{l}\text { Age group, } \mathbf{N} \\
\text { Row \% } \\
\text { Col \% } \\
\end{array}$ & No & Yes & Total & No & Yes & Total \\
\hline $15-25$ & $\begin{array}{l}147,686 \\
77.4 \% \\
17.9 \% \\
\end{array}$ & $\begin{array}{l}43,130 \\
22.6 \% \\
9.1 \%\end{array}$ & $\begin{array}{l}190,816 \\
14.7 \%\end{array}$ & $\begin{array}{l}10,122 \\
28.7 \% \\
12.7 \% \\
\end{array}$ & $\begin{array}{l}25,112 \\
71.3 \% \\
7.8 \% \\
\end{array}$ & $\begin{array}{l}35,234 \\
8.8 \%\end{array}$ \\
\hline $25-34$ & $\begin{array}{l}141,758 \\
69.3 \% \\
17.2 \% \\
\end{array}$ & $\begin{array}{l}62,679 \\
30.7 \% \\
13.2 \% \\
\end{array}$ & $\begin{array}{l}204,437 \\
15.7 \%\end{array}$ & $\begin{array}{l}15,014 \\
27.9 \% \\
18.8 \% \\
\end{array}$ & $\begin{array}{l}38,831 \\
72.1 \% \\
12.1 \% \\
\end{array}$ & $\begin{array}{l}53,845 \\
13.4 \%\end{array}$ \\
\hline $35-44$ & $\begin{array}{l}113,045 \\
62.2 \% \\
13.7 \% \\
\end{array}$ & $\begin{array}{l}68,857 \\
37.9 \% \\
14.5 \% \\
\end{array}$ & $\begin{array}{l}181,902 \\
14.0 \%\end{array}$ & $\begin{array}{l}14,382 \\
24.1 \% \\
18.0 \% \\
\end{array}$ & $\begin{array}{l}45,212 \\
75.9 \% \\
14.0 \% \\
\end{array}$ & $\begin{array}{l}59,594 \\
14.8 \%\end{array}$ \\
\hline $45-54$ & $\begin{array}{l}116,215 \\
54.6 \% \\
14.1 \% \\
\end{array}$ & $\begin{array}{l}96,645 \\
45.4 \% \\
20.4 \% \\
\end{array}$ & $\begin{array}{l}212,860 \\
16.4 \%\end{array}$ & $\begin{array}{l}16,488 \\
19.8 \% \\
20.6 \% \\
\end{array}$ & $\begin{array}{l}66,803 \\
80.2 \% \\
20.7 \% \\
\end{array}$ & $\begin{array}{l}83,291 \\
20.7 \%\end{array}$ \\
\hline $55-64$ & $\begin{array}{l}99,021 \\
50.1 \% \\
12.0 \% \\
\end{array}$ & $\begin{array}{l}98,632 \\
49.9 \% \\
20.8 \% \\
\end{array}$ & $\begin{array}{l}197,653 \\
15.2 \%\end{array}$ & $\begin{array}{l}13,581 \\
16.1 \% \\
17.0 \% \\
\end{array}$ & $\begin{array}{l}70,831 \\
83.9 \% \\
22.0 \% \\
\end{array}$ & $\begin{array}{l}84,412 \\
21.0 \%\end{array}$ \\
\hline $65-74$ & $\begin{array}{l}94,985 \\
55.7 \% \\
11.5 \% \\
\end{array}$ & $\begin{array}{l}75,551 \\
44.3 \% \\
15.9 \% \\
\end{array}$ & $\begin{array}{l}170,536 \\
13.1 \%\end{array}$ & $\begin{array}{l}7,332 \\
11.6 \% \\
9.2 \%\end{array}$ & $\begin{array}{l}56,041 \\
88.4 \% \\
17.4 \% \\
\end{array}$ & $\begin{array}{l}63,373 \\
15.8 \%\end{array}$ \\
\hline $75+$ & $\begin{array}{l}112,736 \\
79.6 \% \\
13.7 \% \\
\end{array}$ & $\begin{array}{l}28,917 \\
20.4 \% \\
6.1 \% \\
\end{array}$ & $\begin{array}{l}141,653 \\
10.9 \%\end{array}$ & $\begin{array}{l}3,052 \\
13.7 \% \\
3.8 \% \\
\end{array}$ & $\begin{array}{l}19,301 \\
86.4 \% \\
6.0 \% \\
\end{array}$ & $\begin{array}{l}22,353 \\
5.6 \%\end{array}$ \\
\hline Total & $\begin{array}{l}825,446 \\
63.5 \% \\
\end{array}$ & $\begin{array}{l}474,411 \\
37,0 \%\end{array}$ & $\begin{array}{l}1,299,857 \\
100 \% \\
\end{array}$ & $\begin{array}{l}79,971 \\
19.89 \\
\end{array}$ & $\begin{array}{l}322,131 \\
80.11\end{array}$ & $\begin{array}{l}402,102 \\
100.0 \% \\
\end{array}$ \\
\hline $\begin{array}{l}\text { Place of living, } \mathbf{N} \\
\text { Row \% } \\
\text { Col \% }\end{array}$ & No & Yes & Total & No & Yes & Total \\
\hline $\begin{array}{l}\text { The Capital } \\
\text { Region of } \\
\text { Denmark }\end{array}$ & $\begin{array}{l}262,620 \\
63.9 \% \\
31.8 \% \\
\end{array}$ & $\begin{array}{l}148,622 \\
36.1 \% \\
31.3 \% \\
\end{array}$ & $\begin{array}{l}411,242 \\
31.6 \%\end{array}$ & $\begin{array}{l}27,798 \\
21.9 \% \\
34.8 \% \\
\end{array}$ & $\begin{array}{l}99,008 \\
78.1 \% \\
30.7 \% \\
\end{array}$ & $\begin{array}{l}126,806 \\
31.5 \%\end{array}$ \\
\hline Region Zealand & $\begin{array}{l}121,320 \\
64.6 \% \\
14.7 \% \\
\end{array}$ & $\begin{array}{l}66,595 \\
35.4 \% \\
14.0 \% \\
\end{array}$ & $\begin{array}{l}187,915 \\
14.5 \%\end{array}$ & $\begin{array}{l}11,779 \\
21.0 \% \\
14.7 \% \\
\end{array}$ & $\begin{array}{l}44,334 \\
79.0 \% \\
13.8 \% \\
\end{array}$ & $\begin{array}{l}56,113 \\
14.0 \%\end{array}$ \\
\hline $\begin{array}{l}\text { The Region of } \\
\text { Southern } \\
\text { Denmark }\end{array}$ & $\begin{array}{l}174,432 \\
63.9 \% \\
21.1 \% \\
\end{array}$ & $\begin{array}{l}98,359 \\
36.1 \% \\
20.7 \% \\
\end{array}$ & $\begin{array}{l}272,791 \\
21.0 \%\end{array}$ & $\begin{array}{l}15,338 \\
18.5 \% \\
19.2 \% \\
\end{array}$ & $\begin{array}{l}67,761 \\
81.5 \% \\
21.0 \% \\
\end{array}$ & $\begin{array}{l}83,099 \\
20.7 \%\end{array}$ \\
\hline $\begin{array}{l}\text { Central Denmark } \\
\text { Region }\end{array}$ & $\begin{array}{l}183,623 \\
62.1 \% \\
22.3 \% \\
\end{array}$ & $\begin{array}{l}111,950 \\
37.9 \% \\
23.6 \% \\
\end{array}$ & $\begin{array}{l}295,573 \\
22.7 \%\end{array}$ & $\begin{array}{l}17,313 \\
18.3 \% \\
21.7 \% \\
\end{array}$ & $\begin{array}{l}77,292 \\
81.7 \% \\
24.0 \% \\
\end{array}$ & $\begin{array}{l}94,605 \\
23.5 \%\end{array}$ \\
\hline $\begin{array}{l}\text { The North } \\
\text { Denmark Region }\end{array}$ & $\begin{array}{l}83,451 \\
63.1 \% \\
10.1 \% \\
\end{array}$ & $\begin{array}{l}48,885 \\
36.9 \% \\
10.3 \% \\
\end{array}$ & $\begin{array}{l}132,336 \\
10.2 \%\end{array}$ & $\begin{array}{l}7,743 \\
18.7 \% \\
9.7 \% \\
\end{array}$ & $\begin{array}{l}33,736 \\
81.3 \% \\
10.5 \% \\
\end{array}$ & $\begin{array}{l}41,479 \\
10.3 \%\end{array}$ \\
\hline Total & $\begin{array}{l}825,446 \\
63.5 \% \\
\end{array}$ & $\begin{array}{l}474,411 \\
36.5 \% \\
\end{array}$ & $\begin{array}{l}1,299,857 \\
100 \% \\
\end{array}$ & $\begin{array}{l}79,971 \\
19.89 \\
\end{array}$ & $\begin{array}{l}322,131 \\
80.1 \% \\
\end{array}$ & $\begin{array}{l}402,102 \\
100.0 \% \\
\end{array}$ \\
\hline
\end{tabular}


medRxiv preprint doi: https://doi.org/10.1101/2021.08.10.21261777; this version posted August 13, 2021. The copyright holder for this preprint (which was not certified by peer review) is the author/funder, who has granted medRxiv a license to display the preprint in It is made available under a CC-BY-ND 4.0 International license .

Supplementary figure 1: Age and sex distribution of the final study population. Numbers above bars represent number of participants in each group.

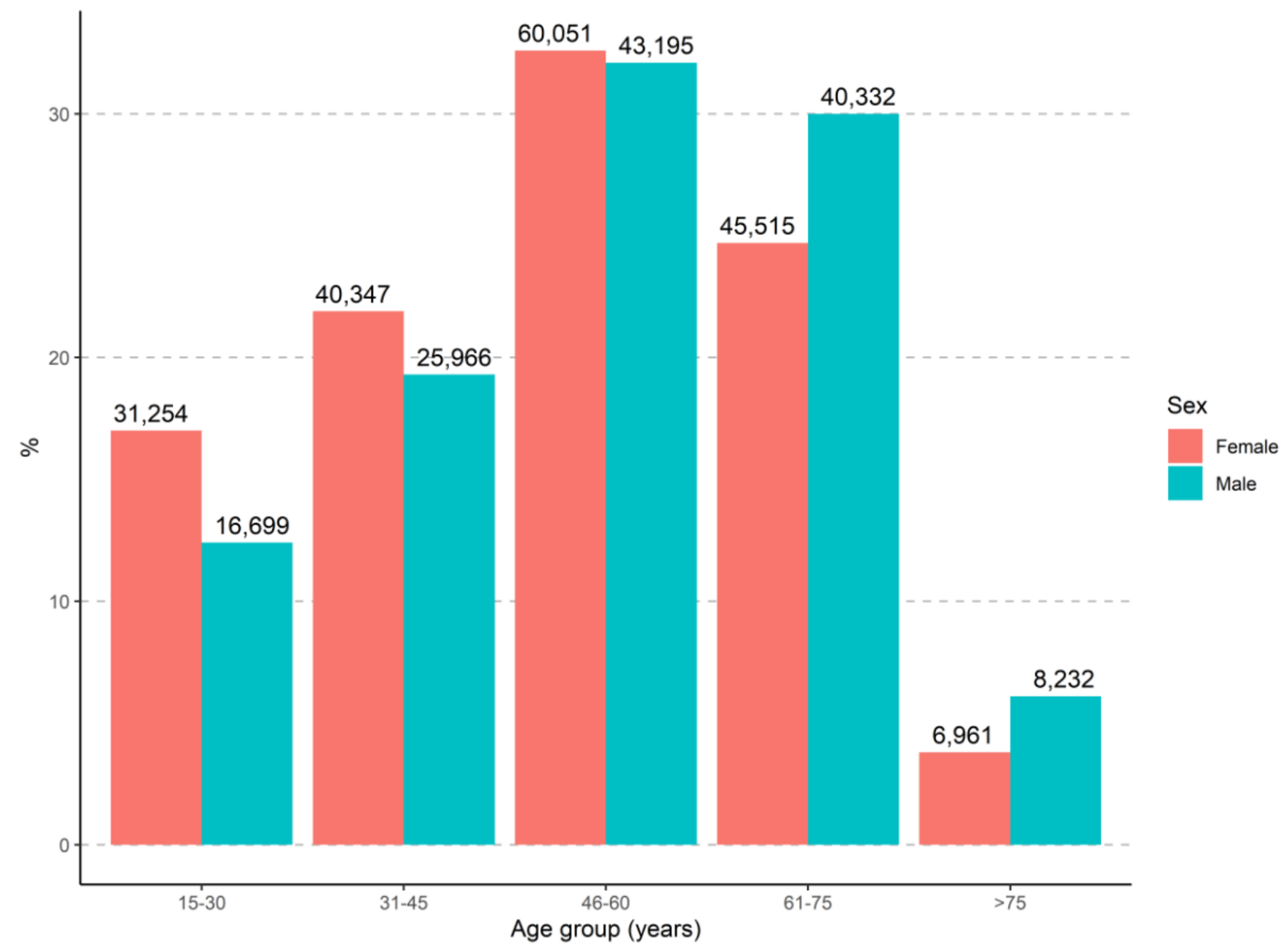


medRxiv preprint doi: https://doi.org/10.1101/2021.08.10.21261777; this version posted August 13, 2021. The copyright holder for this preprint (which was not certified by peer review) is the author/funder, who has granted medRxiv a license to display the preprint in It is made available under a CC-BY-ND 4.0 International license .

Supplementary figure 2: Distribution of SARS-CoV-2 antibodies according to age groups. Numbers above bars represent percentage of total number of participants in groups.

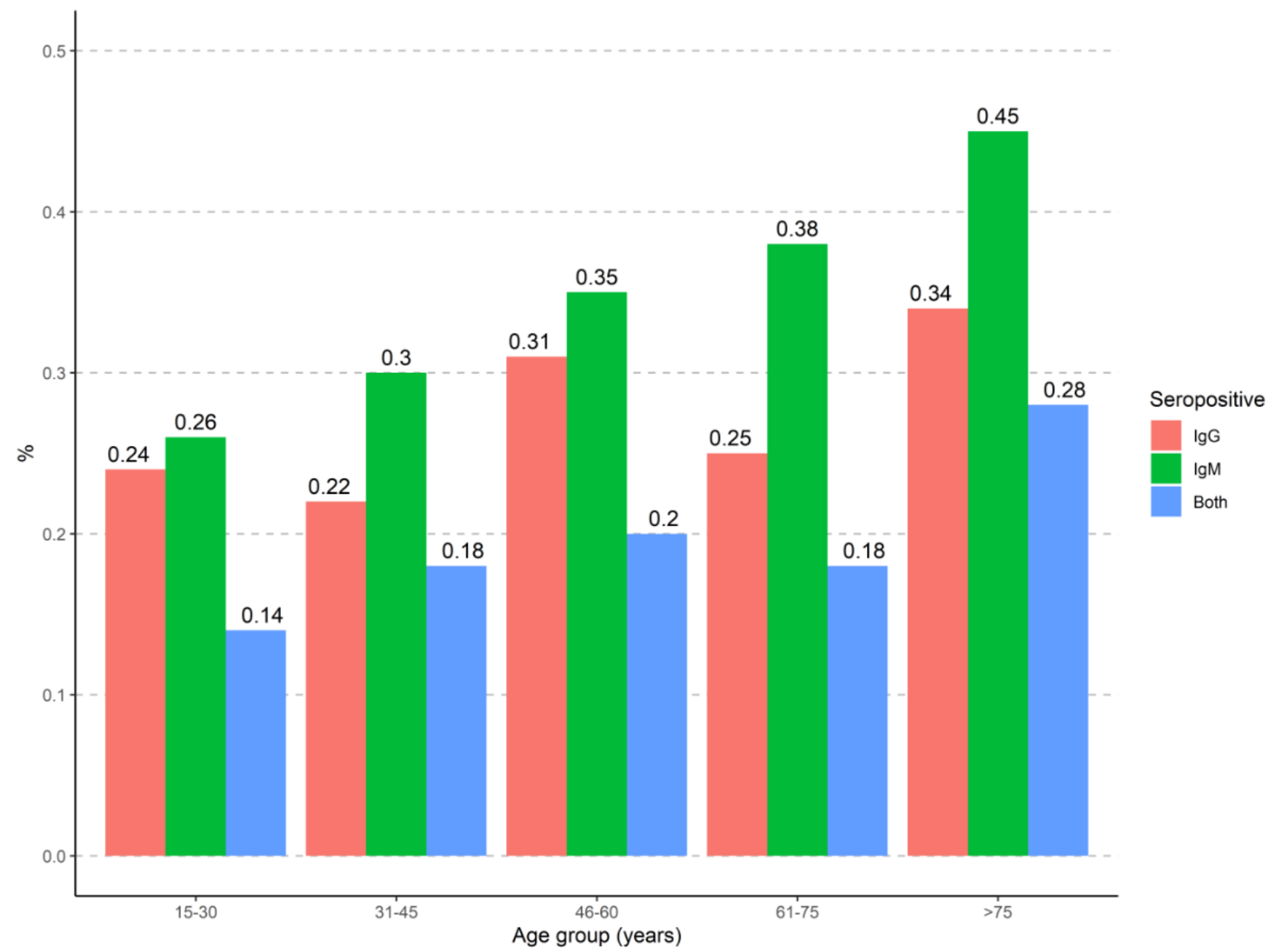


medRxiv preprint doi: https://doi.org/10.1101/2021.08.10.21261777; this version posted August 13, 2021. The copyright holder for this preprint (which was not certified by peer review) is the author/funder, who has granted medRxiv a license to display the preprint in It is made available under a CC-BY-ND 4.0 International license .

Supplementary figure 3: SARS-CoV-2 seropositive \% among 318,552 individuals stratified for age groups and sex. Numbers above bars represent total of participants within each group.

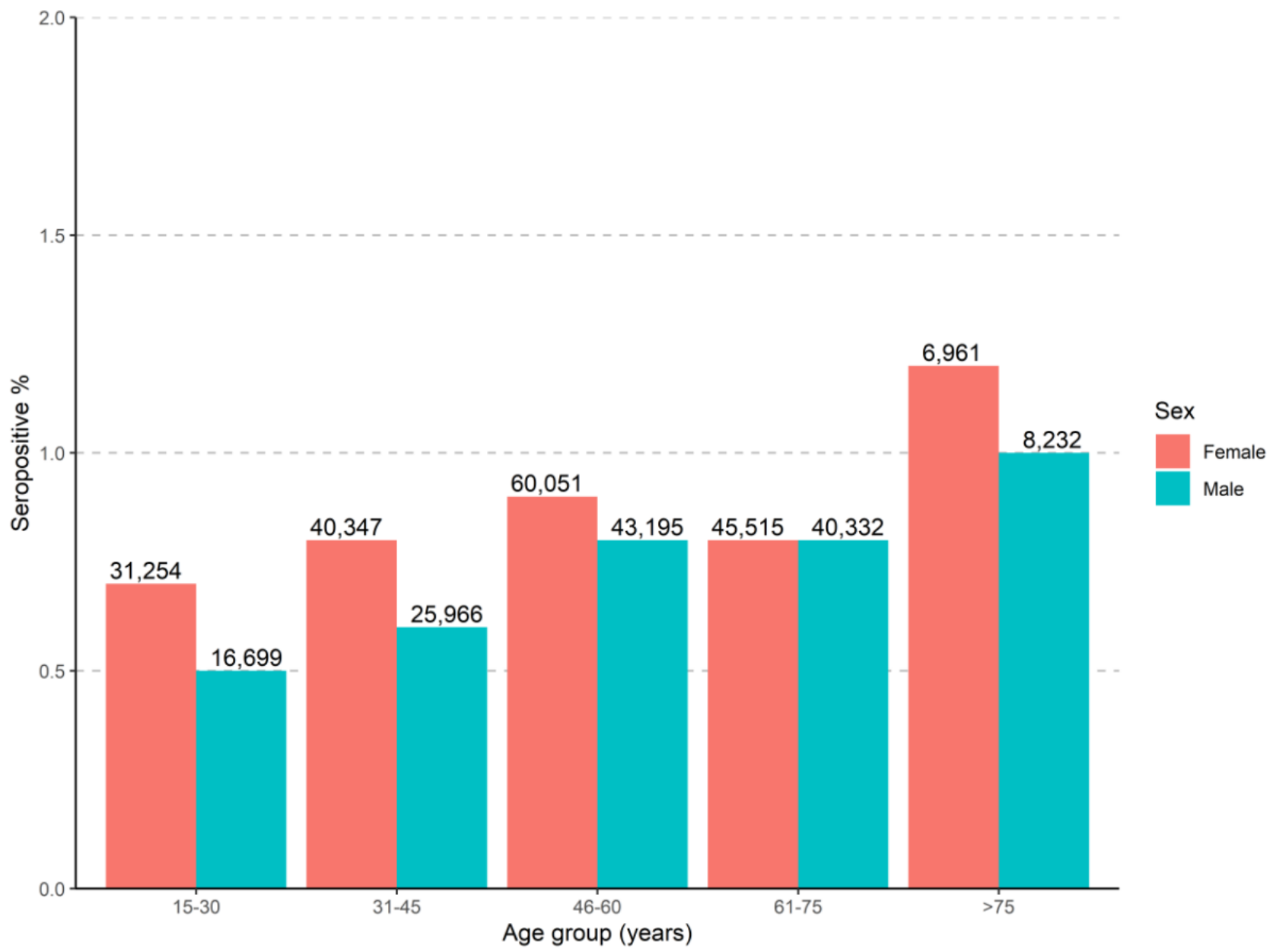

Red: female ( $n, 148,128)$, blue: male ( $n, 134,424)$, number of participants in each group 
medRxiv preprint doi: https://doi.org/10.1101/2021.08.10.21261777; this version posted August 13, 2021. The copyright holder for this preprint (which was not certified by peer review) is the author/funder, who has granted medRxiv a license to display the preprint in It is made available under a CC-BY-ND 4.0 International license .

Supplementary figure 4: SARS-CoV-2 seropositive \% according to smoking habits, weekly alcohol consumption, and BMI stratified for sex. Red bar represents females, blue bar represents males. Numbers above bars represent number of participants in each group.
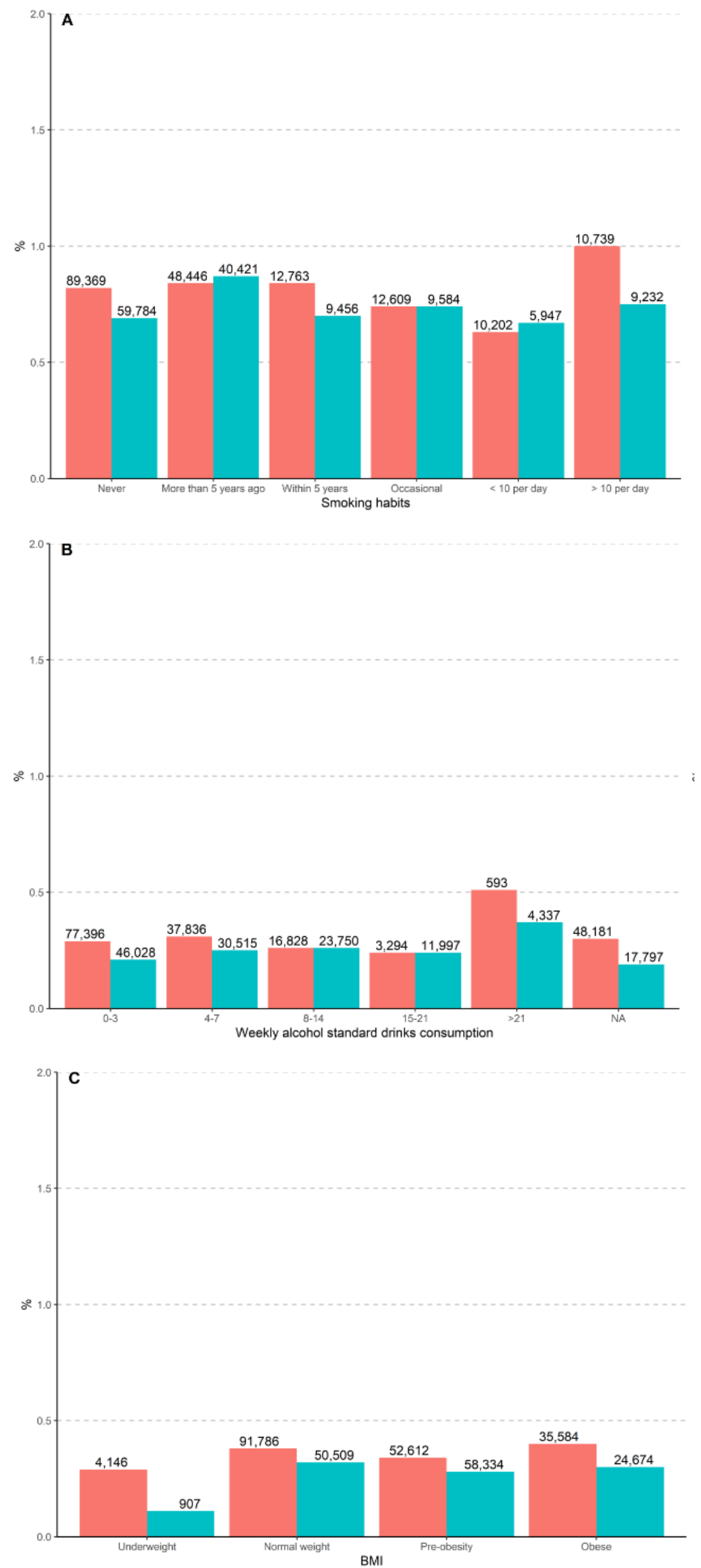
medRxiv preprint doi: https://doi.org/10.1101/2021.08.10.21261777; this version posted August 13, 2021. The copyright holder for this preprint (which was not certified by peer review) is the author/funder, who has granted medRxiv a license to display the preprint in It is made available under a CC-BY-ND 4.0 International license .

Supplementary figure 5: Seropositive \% for self-assed risk of being infected and seropositive \% for participants with a previous positive PCR test. Purple bar represents a subset of 1,828 participants with a positive PCR test prior to POCT test. Red, green, and blue bars represent participants without a prior positive PCR test. The self-assed risk of being infected was compared to the result of POCT test.

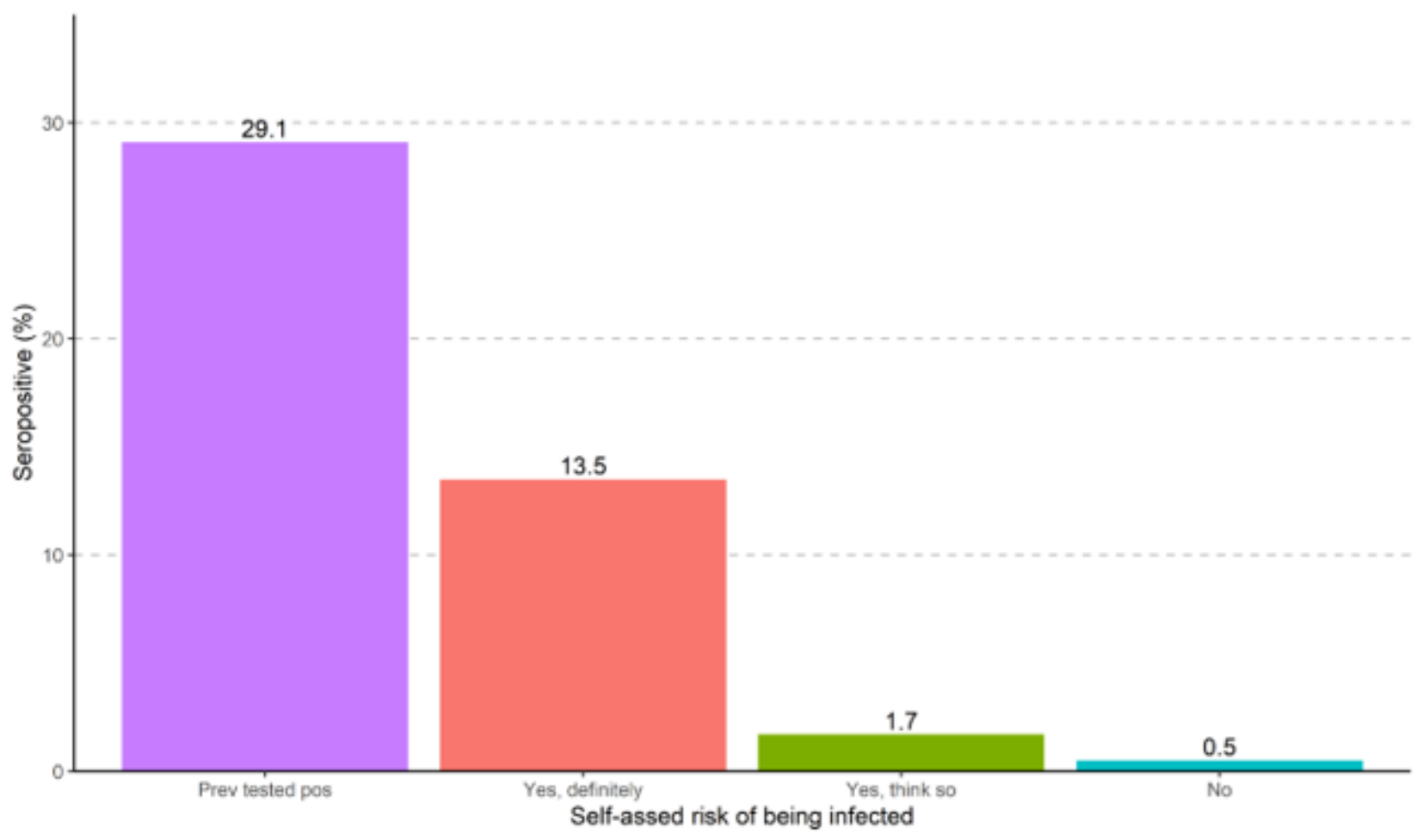


medRxiv preprint doi: https://doi.org/10.1101/2021.08.10.21261777; this version posted August 13, 2021. The copyright holder for this preprint (which was not certified by peer review) is the author/funder, who has granted medRxiv a license to display the preprint in It is made available under perpetuity.

perpetuity.

Supplementary figure 6: Flowchart for identifying participants with a positive PCR test before POCT.

\begin{tabular}{|c|c|c|c|c|c|c|}
\hline $\begin{array}{l}\text { Whole population } \\
318,552\end{array}$ & \multirow[b]{2}{*}{ Participant } & \multirow[b]{2}{*}{\begin{tabular}{|l|} 
Date of PCR \\
YrYY-MM-DD
\end{tabular}} & \multirow[b]{2}{*}{$\begin{array}{l}\text { Date of POCT } \\
\text { YYYY-MM-DD }\end{array}$} & \multirow[b]{2}{*}{ Seropositive? } & \multirow[b]{2}{*}{$\begin{array}{l}\text { Included in } \\
\text { analysis of } \\
\text { sensitivity? }\end{array}$} & \multirow[b]{2}{*}{ Reason } \\
\hline & & & & & & \\
\hline & A & 2020-03-06 & 2020-10-15 & Yes & Yes & Date of $\mathrm{PCR}$ is before POCT. \\
\hline \multirow{6}{*}{$\begin{array}{l}\text { 1,928 participants } \\
\text { ALL with a previous } \\
\text { positive PCR test. }\end{array}$} & B & 2020-03-06 & Missing & No & Yes & $\begin{array}{l}\text { Date of PCR is before POCT as earliest possible } \\
\text { POCT date is 2021-10-01. }\end{array}$ \\
\hline & c & 2020-10-15 & 2020-10-17 & No & Yes & Date of PCR is before. \\
\hline & D & $2020-10-25$ & 2020-10-06 & Yes & No & Date of PCR is after POCT. \\
\hline & $E$ & $2020-10-25$ & Missing & No & No & $\begin{array}{l}\text { POCT date is missing and could have been } \\
\text { performed after PCR. }\end{array}$ \\
\hline & & & & & \multicolumn{2}{|c|}{$\begin{array}{l}100 \text { excluded as we cannot be } \\
\text { sure that date of PCR test was } \\
\text { before POCT }\end{array}$} \\
\hline & & & \multicolumn{3}{|c|}{$\begin{array}{l}1,828 \text { participants with a } \\
\text { previous positive } P C R \text { test } \\
\text { before } P O C T\end{array}$} & \\
\hline
\end{tabular}


medRxiv preprint doi: https://doi.org/10.1101/2021.08.10.21261777; this version posted August 13, 2021. The copyright holder for this preprint (which was not certified by peer review) is the author/funder, who has granted medRxiv a license to display the preprint in perpetuity.
It is made available under a CC-BY-ND 4.0 International license .

Supplementary figure 7: SARS-Cov-2 seropositive $\%$ among 804 individuals by POCT stratified for days since positive PCR.

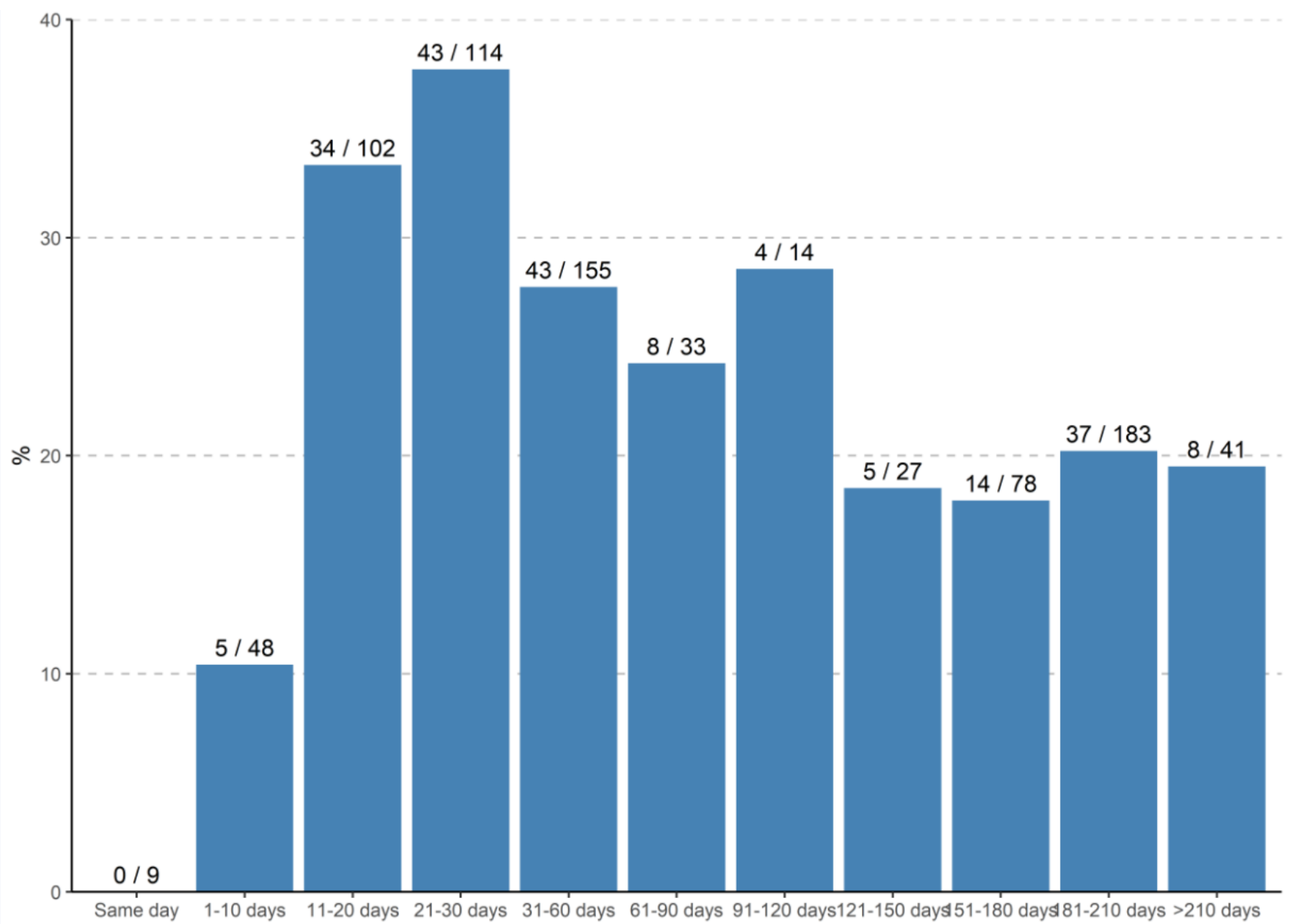


medRxiv preprint doi: https://doi.org/10.1101/2021.08.10.21261777; this version posted August 13, 2021. The copyright holder for this preprint (which was not certified by peer review) is the author/funder, who has granted medRxiv a license to display the preprint in It is made available under a CC-BY-ND 4.0 International license.

Supplementary figure 8: Map of seropositivity for each municipality.

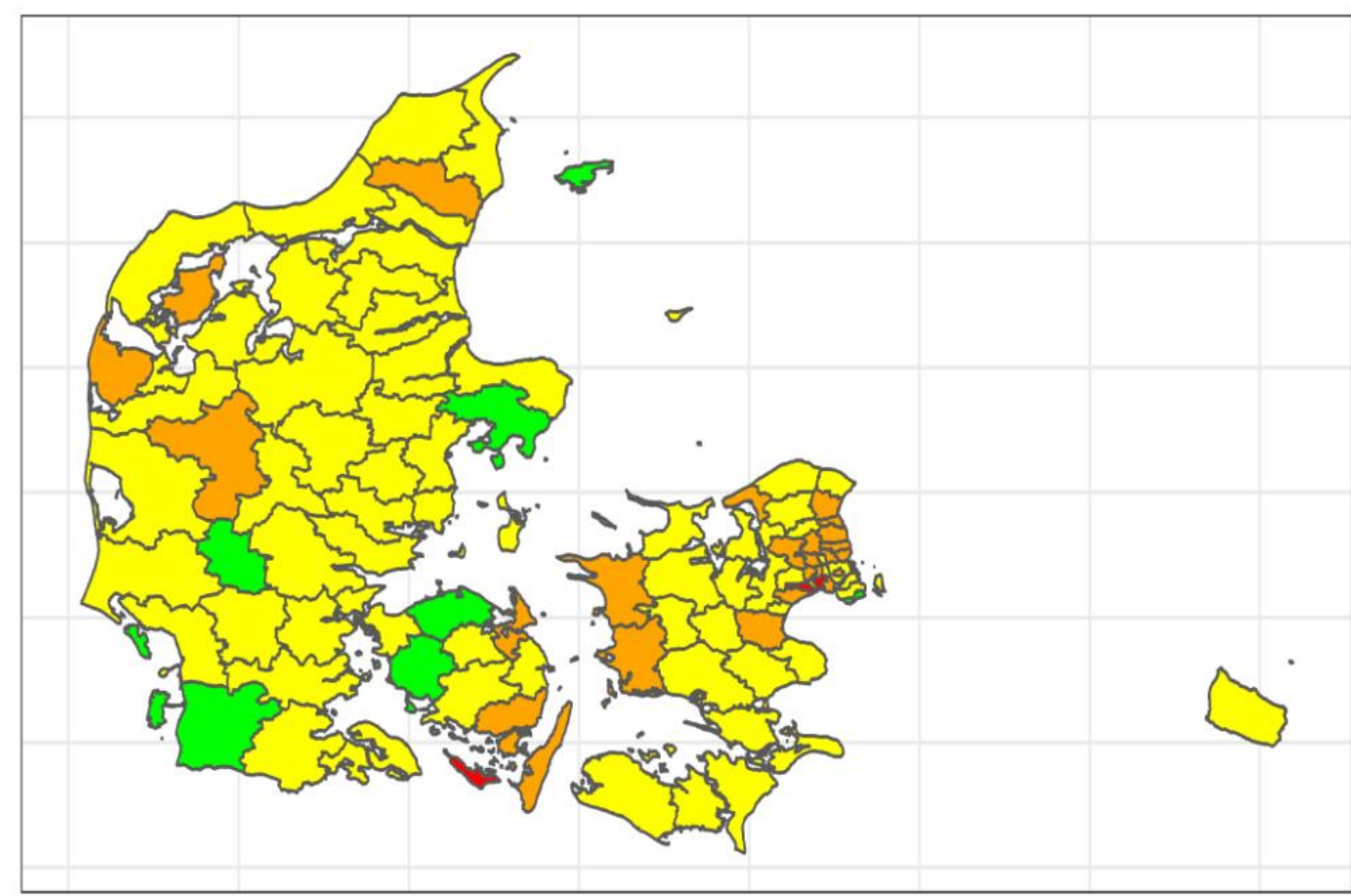

Seropositive \%

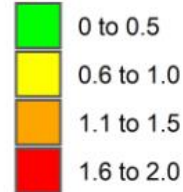


medRxiv preprint doi: https://doi.org/10.1101/2021.08.10.21261777; this version posted August 13, 2021. The copyright holder for this preprint (which was not certified by peer review) is the author/funder, who has granted medRxiv a license to display the preprint in It is made available under a CC-BY-ND 4.0 International license .

Supplementary figure 9: Scatterplot of seropositive \% according to population density for all municipalities. Each $x$-axis tick represents a municipality with the corresponding population density. Dots, triangles, squares, and crosses represent population density quartiles from lowest to highest quartile, respectively.

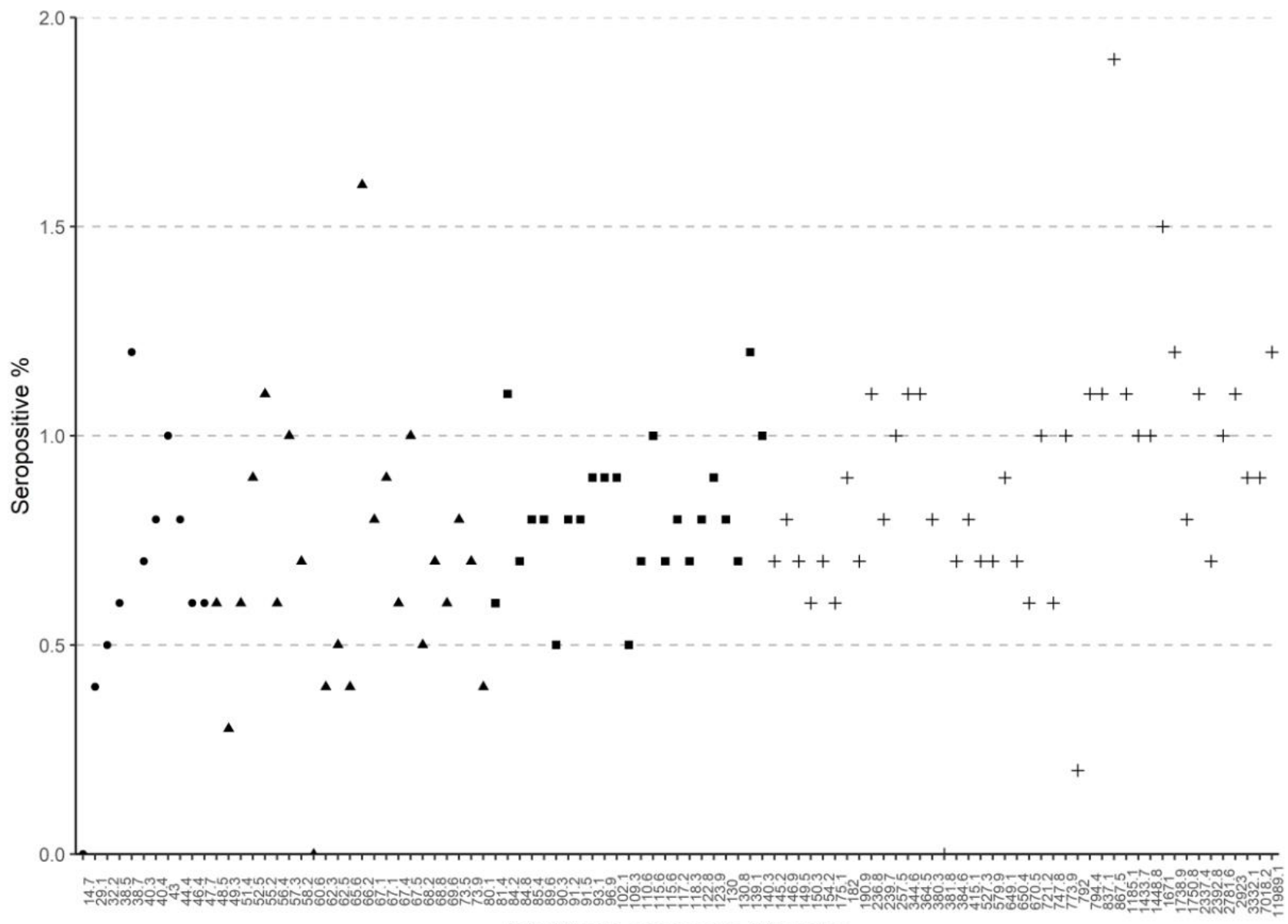

Inhabitants per square kilometer 
medRxiv preprint doi: https://doi.org/10.1101/2021.08.10.21261777; this version posted August 13, 2021. The copyright holder for this preprint (which was not certified by peer review) is the author/funder, who has granted medRxiv a license to display the preprint in It is made available under a CC-BY-ND 4.0 International license .

Supplementary figure 10: SARS-CoV-2 seropositive \% in households with a COVID-19 infected person stratified by household size. Numbers above bars represent number of seropositive and seronegative participants in each household size.

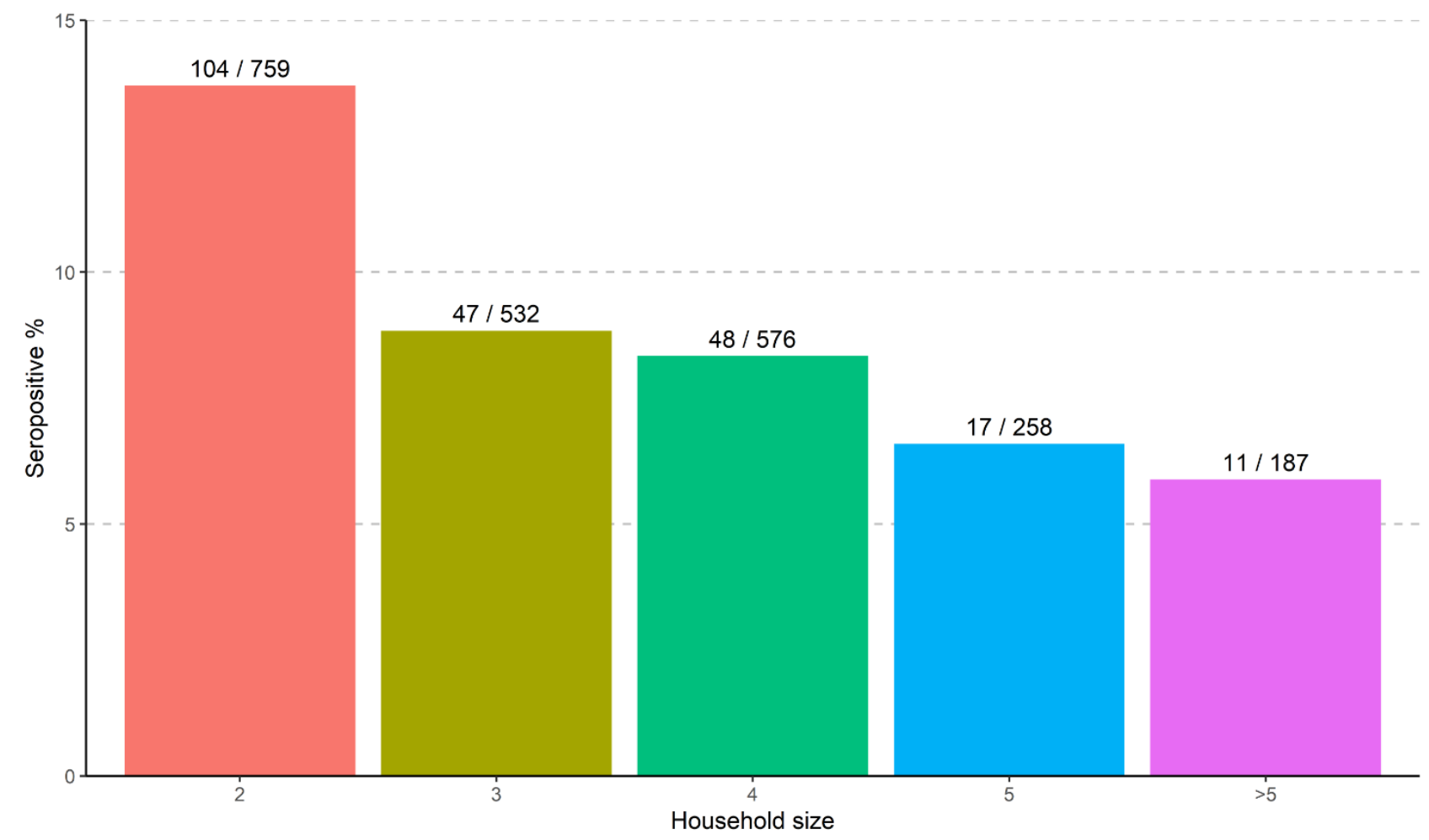


medRxiv preprint doi: https://doi.org/10.1101/2021.08.10.21261777; this version posted August 13, 2021. The copyright holder for this preprint (which was not certified by peer review) is the author/funder, who has granted medRxiv a license to display the preprint in It is made available under a CC-BY-ND 4.0 International license .

Supplementary figure 11: Proportion of persons who experienced symptoms stratified for age groups. Numbers next to bars represent percentages.
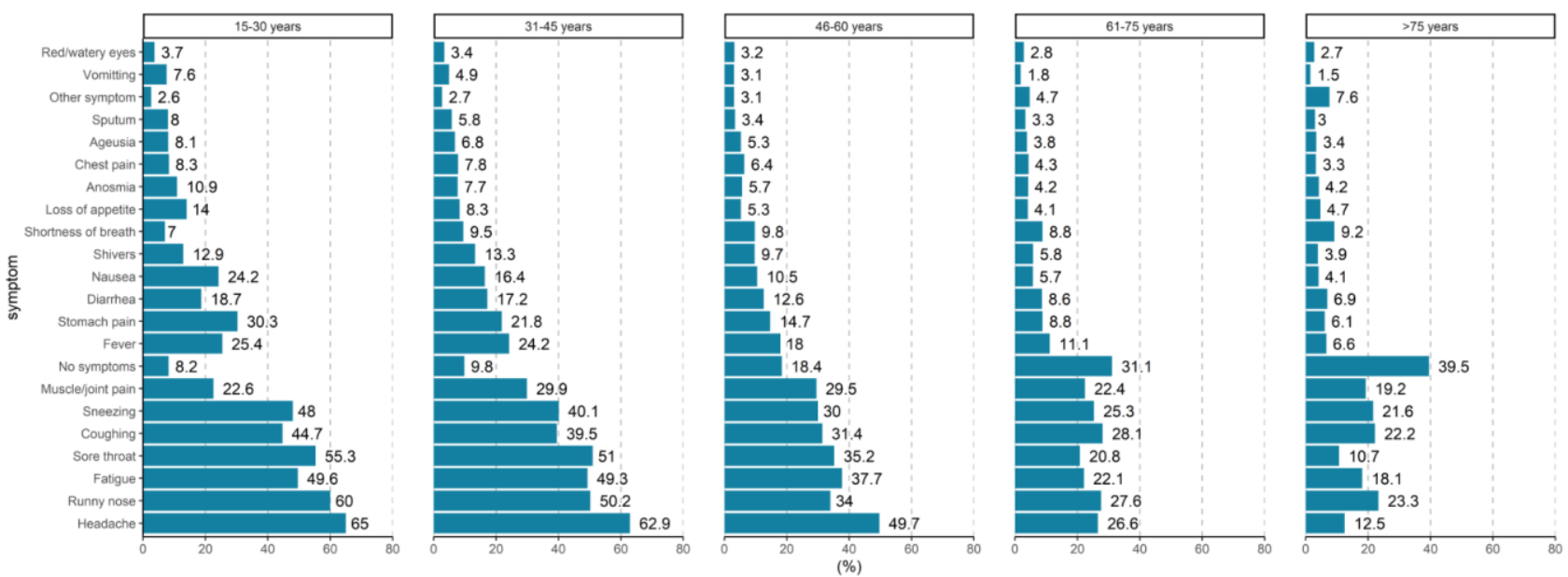
medRxiv preprint doi: https://doi.org/10.1101/2021.08.10.21261777; this version posted August 13, 2021. The copyright holder for this preprint (which was not certified by peer review) is the author/funder, who has granted medRxiv a license to display the preprint in It is made available under a CC-BY-ND 4.0 International license .

Supplementary figure 12: Number of previous tests for 318,552 participants stratified for age groups and sex.

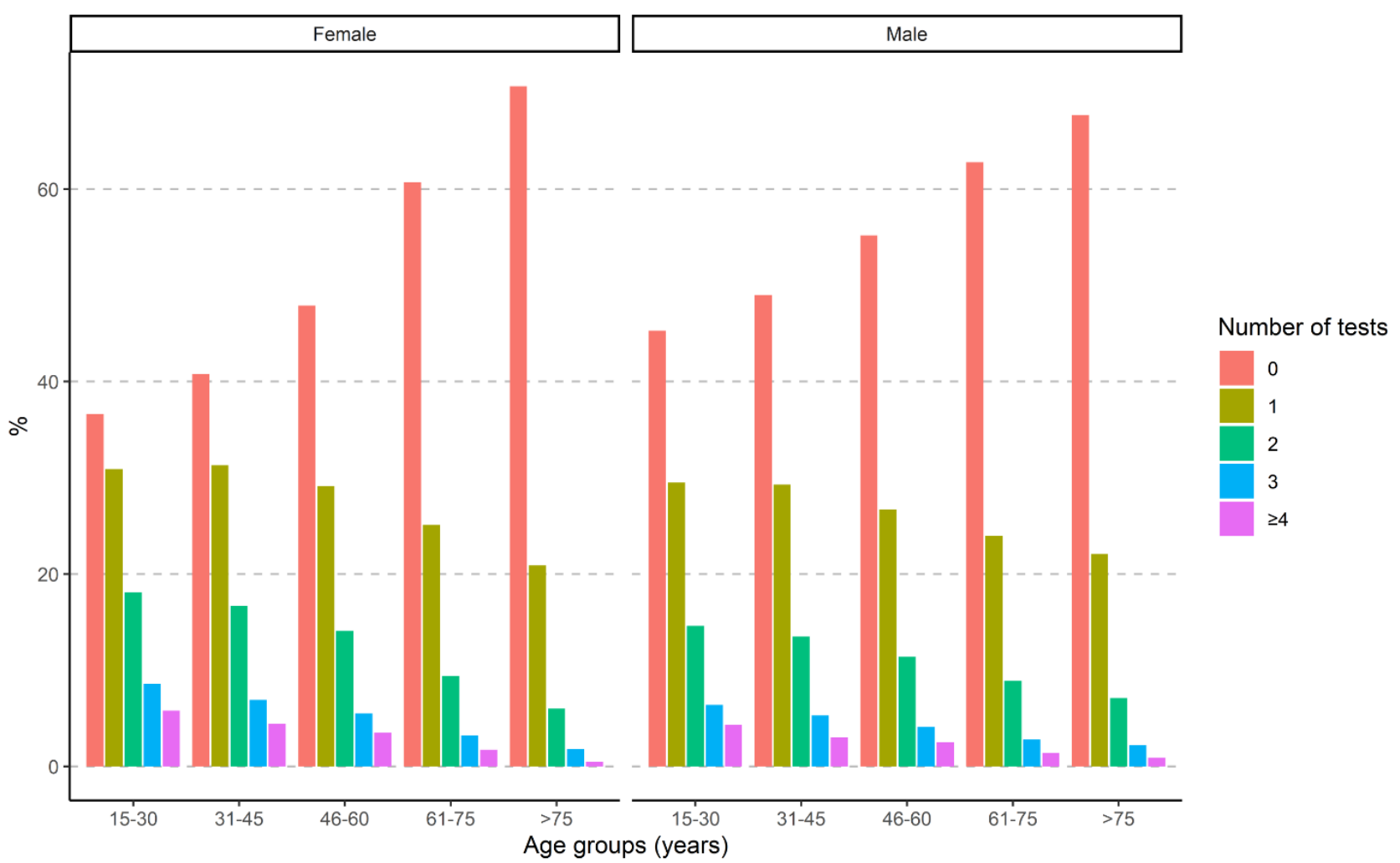


medRxiv preprint doi: https://doi.org/10.1101/2021.08.10.21261777; this version posted August 13, 2021. The copyright holder for this preprint (which was not certified by peer review) is the author/funder, who has granted medRxiv a license to display the preprint in It is made available under a CC-BY-ND 4.0 International license .

\section{Appendix}

Table 4: In house validation (cases=600 individuals, controls=150 individuals)

\begin{tabular}{|l|r|r|r|r|r|}
\hline LIVZON \\
\hline Batchnummer & Expiration date for POCT & Sensitivity & $\mathbf{9 5 \%}$ Cl & Specificity & $\mathbf{9 5 \%} \mathbf{~ C l}$ \\
\hline CK2004310410 & 14.10 .2020 & $93.3 \%$ & $88.1-96.7$ & $98.2 \%$ & $96.7-99.1$ \\
\hline CK2004350410 & 19.10 .2020 & $92.7 \%$ & $87.3-96.3$ & $97.5 \%$ & $95.9-98.6$ \\
\hline
\end{tabular}


medRxiv preprint doi: https://doi.org/10.1101/2021.08.10.21261777; this version posted August 13, 2021. The copyright holder for this preprint (which was not certified by peer review) is the author/funder, who has granted medRxiv a license to display the preprint in It is made available under a CC-BY-ND 4.0 International license .

\section{The questionnaire:}

1. Testing Denmark NOTE it is no longer possible to sign up for the antibody testing. It will still to be very valuable to us if you will take the time to fill out the questionnaire.

2. Questions about infection with COVID-19

3. If you were to give your best bet, do you think/know that you have ever been infected with COVID-19?

4. Have you previously been tested for COVID-19?

5. How many times have you been tested for COVID-19?

6. What type of COVID-19 test have you had? (Feel free to give multiple answers)

7. Was one or more of your tests positive?

8. Symptoms

9. How often do you usually have a cold or influenza-like symptoms?

10. Have you had any of the following symptoms in the period since 1 February 2020 ?

11. How many times have you had a fever since 1 February 2020 ?

12. How many times have you had chills since 1 February 2020 ?

13. How many times have you had runny or stuffy nose since 1 February 2020 ?

14. How many times have you had an impaired sense of smell since 1 February 2020 ?

15. How many times have you had an impaired sense of taste since 1 February 2020 ?

16. How many times have you had periods with sneeze since 1 February 2020 ?

17. How many times have you had a sore throat since 1 February 2020 ?

18. How many times have you had a cough since 1 February 2020 ?

19. How many times did you experience difficulty in breathing/shortness of breath since 1 February 2020 ?

20 . How many times have you had a headache since 1 February 2020 ?

21. How many times have you experienced muscle and/or joint pain since 1 February 2020 ?

22 . How many times have you had chest pain since 1 February 2020 ?

23. How many times have you experienced fatigue and exhaustion since 1 February 2020 ?

24. How many times have you experienced a loss of appetite since 1 February 2020 ?

25. How many times have you experienced coloured sputum (spit)/mucus since 1 February 2020 ?

26. How many times have you had bloodshot, watery eyes since February 12020 ?

27 . How many times have you experienced nausea since 1 February 2020 ?

28 . How many times have you vomited since 1 February 2020 ?

29. How many times have you had diarmoea since 1 February 2020 ?

30. How many times have you had stomach pain since 1 February 2020 ?

31. How many times have you had other symptoms since 1 February 2020 ?

32. In which months since 1 February did you experience fever?

33. In which months since 1 February did you experience chills?

34. In which months since 1 February did you experience a runny or stuffy nose?

35. In which months since 1 February did you experience an impaired sense of smell?

36. In which months since 1 February did you experience an impaired sense of taste?

37. In which months since 1 February did you experience sneezing?

38. In which months since 1 February did you experience a sore throat?

39. In which months since 1 February did you experience a cough?

40. In which months since 1 February did you experience difficulty breathing?

41. In which months since 1 February did you experience headaches?

42. In which months since 1 February did you experience muscle and/or joint pains?

43. In which months since 1 February did you experience chest pains?

44. In which months since 1 February did you experience fatigue and exhaustion?

45. In which months since 1 February did you experience a loss of appetite?

46. In which months since 1 February did you experience coloured sputum (spit)/mucus?

47. In which months since 1 February did you experience bloodshot, watery eyes?

48. In which months since 1 February did you experience nausea?

49. In which months since 1 February did you experience vomiting?

50. In which months since 1 February did you experience diarrhoea?

51. In which months since 1 February did you experience stomach pains?

52. In which months since 1 February did you experience other symptoms? 
medRxiv preprint doi: https://doi.org/10.1101/2021.08.10.21261777; this version posted August 13, 2021. The copyright holder for this preprint (which was not certified by peer review) is the author/funder, who has granted medRxiv a license to display the preprint in It is made available under a CC-BY-ND 4.0 International license .

53. Did you take your temperature when you had a fever?

54. What was your highest measured temperature?

55. Did your symptoms occur suddenly (over a few hours)?

56. Did you take any medication for your symptoms?

57. What do you think is/was the cause of your symptoms? (Feel free to give multiple answers)

58. Which of the following conditions best describes how you felt when you were feeling the worst, while you had/suspected you had COVID-19?

59. Risk of COVID-19

60. Since 1 February, have you at any time been in contact with/in proximity to someone whom you knew had tested positive for COVID-19? That is within seven days before or after this person tested positive for COVID-19?

61. Contact with infected

61.1 Have you stayed for minimum 15 minutes in the same room as an infected person?

61.2 Have you had body contact with a person infected with COVID-19?

61.3 Have you worked/studied with someone who was infected with COVID-19?

61.4 Has someone in your household been infected with COVID-19?

61.5 Has someone in your family or a friend outside your household been infected with COVID-19?

62. Have you traveled abroad since 1 February 2020 ?

63. Approximately how many times have you traveled abroad (with sleepover) since 1 February 2020

64. Which of the following countries have you traveled to (with sleepover) since 1st of february (feel free to give multiple answers)

65. This part concerns behaviour

66. Have you taken any of the following measures in the past 14 days due to the risk of COVID-19 infection? (Feel free to give multiple answers)

67. Which of the statements below apply to you?

68. Have you consumed alcohol in the past 12 months?

69. On how many days a week do you drink alcohol on average?

70. How many units do you typically drink a week?

71. 1 unit $=$

72. Chronic illness. Information about any chronic illness, height, weight and lifestyle is important to enable us to assess whether you are at a particular risk of COVID-19.

73. For each of the following diseases and health problems, please state whether you currently suffer from it or have previously suffered from it.

73.1 Asthma

73.2 Allergy (other than asthma)

73.3 Diabetes

73.4 High blood pressure

73.5 Heart attack

73.6 Stroke

73.7 Chronic bronchitis, hyperinflated (enlarged) lungs, smoker's lungs (emphysema, COPD)

73.8 Rheumatoid arthritis

73.9 Cancer

73.10 Other chronic disease

74. What other chronic disease

75. How much do you weigh in kilograms $(\mathrm{kg})$ ?

76. How tall are you in centimetres $(\mathrm{cm})$ ?

77. Did you get an influenza vaccine last autumn/winter 2019-2020?

78. Work and education

79. What is your highest level of completed education?

80. What is your main occupation?

81. Which area(s) or type(s) of work best describe(s) your work? (Feel free to give multiple answers)

82. Are you in contact with patients in your work?

83. Have you worked with patients hospitalised with COVID-19?

84. The following questions concern your household

85. How many people in the following age groups, including yourself, live in your household? 
medRxiv preprint doi: https://doi.org/10.1101/2021.08.10.21261777; this version posted August 13, 2021. The copyright holder for this preprint (which was not certified by peer review) is the author/funder, who has granted medRxiv a license to display the preprint in It is made available under a CC-BY-ND 4.0 International license .

85.1 0-4-year-olds

85.2 5-18-year-olds

85.3 19-44-year-olds

85.4 45-64-year-olds

$85.565+$-year-olds

86. The following questions concern your perception of your health

87. In general would you say your health is

88. How do you experience your health now relative to last year at the same time?

89. The following questions are about activities you might do during a typical day.

90. Does your health now limit you in these activities? If so, how much?

90.1 Moderate activities, such as moving a table, pushing a vacuum cleaner or bicycling

90.2 Climbing several flights of stairs

90.3 Hard activities, such as sports, running or other hard physical activity

91. Have you had any of the following problems with your work or other day-to-day activities due to your physical health in the past four weeks?

91.1 I've managed less than I would've liked to

91.2 I've been restricted in the kind of work or other activities I've been able to perform

92. During the past 4 weeks, have you been limited in daily activities due to physical pain (including activities at home and at work)?

93. How do you experience your discomfort from pain now relative to last year at the same time?

94. How do you experience your physical health now relative to last year at the same time?

95. Have you had any of the following problems with your work or other day-to-day activities due to emotional problems in the past four weeks?

95.1 I've managed less that I would've liked to

95.2 I have performed my work or other activities less carefully than I usually do

96. How do you experience your emotional health now relative to last year at the same time?

97. These questions are about how you have felt in the past four weeks. How much of the time in the past four weeks have you

97.1 ... felt calm and peaceful

97.2 ... been full of energy

97.3 ... felt downhearted and blue

98. Within the past four weeks, how much of the time has your physical health or emotional problems made it difficult for you to see other people (e.g. visit friends, relatives etc.)?

99. If you have elaborating comments on the questions, you can write them here

100. Special health problems now and a year ago

101. If you have obvious explanations for your problems yourself, you can state them in a box at the end. For each condition, please state how this has changed relative to last year $-5=$ Much worse $0=$ The same $5=$ Much better

102. Fatigue - Relative to last year

103. Dry cough - Relative to last year

104. Chest discomfort - Relative to last year

105. Shortness of breath/difficulty breathing when walking at a brisk pace or running - Relative to last year

106. Shortness of breath/difficulty in breathing when walking at an easy pace or light work, e.g. vacuuming or gardening - Relative to last year

107. Shortness of breath/difficulty breathing when talking - Relative to last year

108. Shortness of breath/difficulty breathing when resting - Relative to last year

109. Headache - Relative to last year

110. Dizziness - Relative to last year

111. Pain in muscles and joints - Relative to last year

112. Nausea - Relative to last year

113. Vomiting - Relative to last year

114. Constipation - Relative to last year

115. Diarrhoea - Relative to last year

116. Tingling sensations in hands or feet - Relative to last year

117. Difficulty concentrating - Relative to last year 
medRxiv preprint doi: https://doi.org/10.1101/2021.08.10.21261777; this version posted August 13, 2021. The copyright holder for this preprint (which was not certified by peer review) is the author/funder, who has granted medRxiv a license to display the preprint in

It is made available under a CC-BY-ND 4.0 International license .

118. Difficulty remembering things that have just happened (short-term memory) - Relative to last year

119. Difficulty remembering things that happened a long time ago (long-term memory) - Relative to last year

120. Sensitivity to light - Relative to last year

121. Sensitivity to sound - Relative to last year

122. You quickly become tired when looking at a screen (computer, iPad, TV and the like) - Relative to last year

123. Reduced or altered sense of taste - Relative to last year

124. Reduced or altered sense of smell - Relative to last year

125. Have you had an unintended change in your weight over the past year?

126. If you have elaborating comments on the questions, you can write them here

127. Your mood

128. During the past two weeks, have you had little interest or joy in doing things?

129. During the past two weeks, have you felt down, depressive or had a feeling of hopelessness?

130. How do you experience your mood now relative to last year at the same time?

131. If you have elaborating comments on the questions, you can write them here

132. Antibody test

133. Would you like to be sent a home test which you can use to test whether you have COVID-19 antibodies?

134. Thank you so much for participating in the survey!

135. Thank you so much for participating in the survey! 